\title{
مدخل إلى تحقيق النصوص التراثية
}

\section{An introduction to Heritage Texts Verification}

أ. دـ/ محمود مهدي بـوي*

\section{mmm.badwy@hotmail.com}

المستخلص

ترك لنا علماؤنا تراثًا معرفيَّا عظيمًا كمَّا وكيفًا، فعلى مدار أكثر من عشرة قرون ومِداد أقلامهم لا يجف، فألفوا في شتى العلوم العربية، والشرعية، والفلسفة والمنطق، والتاريخ والجغرافيا، والاجتماع، والطب والصيدلة والكيمياء والطبيعة، والميكانيكا، والفلك، والتاريخ الطبيعي، وغيرها، واستطاعوا بعلومهم وتآليفهم أن ينيـروا درب البشـرية المظلـم، وأن يضــوا لبنـات كثيـرة فـي صـرح الحضــارة الإنسانية.

هذا التراث الذي حفظته المكتبات الخاصـة والعامـة هو ما نعوّل على كثير منه في حياتنا اليوم، وتدور حول نصوصه الدراسات المتنوعة. وكثير من هذه النصوص وقع ناسخوها في تصحيفات وتحريفات وأخطاء بلا قصد، كما تعددت نُسـخ بعض الكتب، واختلفت روايات بعض النصوص، ولو نشرت كل نسخة منها على حدة لوجد المتلقى في هذه النشرات تعارضًا ونقصًا وزيادة وتصحيفًا وتحريفًا.

* الخبير بمركز التراث العربي بجامعة مصر للعلوم والتكنولوجيا، ونائب مدير المركز.

أ.د / محمود مهدي بدوي

(مدخل إلى تحقيق النصوص التراثية) 
من هنا كان تحقيق النصوص للوصول بها إلى أقرب صسورة تركها عليها

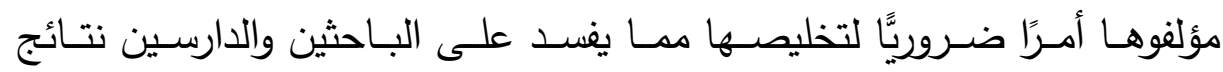
أعمالهم، ويضيع وقتهم وجهدهم هباء. وقد جاء هذا المدخل ليقلي الضـوه بإيجاز على أهم قواعد تحقيق النص التراثي، مقرونة عناصره وقواعده بنماذج مصوَّة من المخطوطات لتضفي مزيدًا من التوضيح والبيان. الكلمـات المفتاحيـة: التـراث العربـي، تحقيق النصـوص، جمـع النسـخ، النَّــخ والمقابلة، الملاحق. 


\section{$\underline{\text { Abstract }}$}

Our scholars have left a great legacy of knowledge, both quantitatively and qualitatively. Over a course of more than ten centuries, the scholars' pens ink has not dried out yet. They wrote books on various Arab sciences such as jurisprudence, philosophy, logic, history, geography, sociology, medicine, pharmacy, chemistry, physics, mechanics, astronomy, and biology, etc. Armed with these sciences, they were able to enlighten humanity and magnificently contribute to building the edifice of the human civilization.

This legacy, which was preserved by private and public libraries, is what we rely on too much in our lives today and dealt with its content in various studies.

Many of these texts were mistakenly misrepresented by their copyists. books were duplicated. The narrations of some texts were altered, and if each copy has been published separately, the recipient would find a contradiction in these publications, shortage, addition and distortion.

Hence, it is an obligatory to verify these texts so as to bring them to the closest concepts of their origin and free them of what negatively affect on researchers' and scholars' work and waste their time and efforts.

This introduction was written to cast light briefly on the most important rules for verifying the heritage text, coupled with

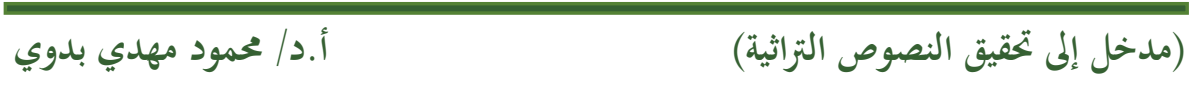


its elements and rules and illustrated manuscript models to give more clarification and manifestation.

Keywords: Arab heritage - Text Verification - Collection of copies - Copying and Comparison - Appendices. 


\section{مقدمة}

يمتاز التراث العربي بِبُعدَيْه: الزماني والمكاني اللذَيْن تمخضت عنهما ثروة علمية مخطوطة قُدِر المفهرَس منها بأكثرَ من ثلاثة ملايين مخطوطة موزعةً على مكتبات العالم في فنون شتَّى شملت العلوم النقلية والعقلية، وقد تميز كثير منها بعنايسة مؤلفيها وناسخيها ومزخرفيها ومذِِّيها ومجلِّديها، فخرجت آيـة في الجمال المادي والدقة العلمية.

ويعدّ التراث العربي المخطوط وثيقةً حيـةً تؤكد مسـاهمة علمائنسا في بنـاء

صـرح الحضـارة العالميـة، كمـا أنـه المـرآة التي تعكس صـورة جهودهم، وتبـرز تفـوقهم، وتجســـ مهـاراتهم، وتبـين ميـادين نبـوغهم فـي شـتى الفــون والعــوم والمعارف.

وإذا كانت الأمم ذاتُ الماضي القريب والتراث المحدود تبذل جهودًا مضـاعفةً للحفاظ على تراثها وإحيائه، فعنايتنا بتراثنا يجب أن تكون أكبر ، ورعايتنا له أشد، وإحياؤنا له واجب على كل من يملك مقومات سلوك هذا الدرب، ودراسته لإبراز مكنونه وإيضاح إسراره وبيان مقدار الجهود التي بذلت فيه أمر ضروري. لكن الواقع يخالف الواجب، فثروتنا التراثية المخطوطة عادت عليها عوادي الحروب والحقد والفتن المذهبية والطائفية والإهمال، فدُمِّر منها ما دُمِّر، ونُهب وهرِب منها الكثير ، وتَلَفَ منها ما لا يحصى. ويعد تحقيق ما بقي من نصوصه خطوة ضرورية في سبيل إحياء هذا التراث ليقف دارسوه وناقدوه ومؤرخوه على مواطن قوته وضعفه، ومقدار مساهمته في النهضة العلمية الحديثة. 
وقد عرف علماؤنا القدامى الكثير من قواعد التحقيق وطبقوها على أعمالهج، فهذا حنين بن إسحاق يبين ما فعله بكتاب "في الفرق " لجالينوس فيقول: " ثم سألني بعد ذلك وأنا من أبناء أربعين سنة أو نحوها حبيش تلميذي إصـلاحه بعد أن كانت قد اجتمعت لله عندي نسـخ يونانية فقابلت تلك بعضهها ببعض حتى صحت منه نسخة واحدة، ثم قابلت بتلك النسخة السرياني وصححته1" ، ويقول عن صنيعه في كتاب "حيلة البرء " لجالينوس:" ثم إني بعد سنين ترجمت الكتاب من أوله لبختيشوع بن جبريل، وكانت عندي للثماني المقالات الأخيرة منه عدة نسخ باليونانية فقابلت بها وصححت منها نسخة وترجمتها بغاية ما أمكنني من الاستقصـاء والبلاغة 2"، والعلموي في كتابه يقول قاصدا طالب العلم:" عليه مقابلة كتابه بأصل صحيح موثوق به، فالمقابلة متعينة للكتاب الذي يرام النفع به" "وما صنيع حنين والعلموي وغيرهما كالقاضي3 عياض إلا من صميم تحقيق النصوص. ولم تكن المقابلة وحدها هي من عرفها علماؤنا من قواعد التحقيق، بل عرفوا أيضـا عـلاج السقطُ، وعلامـات الإحالة أو الإحساق، وكيفية معالجـة الزيـادة5 واسـتبعادهامن النص، وضـبط الكلمـات بـالحروف، وصـنع الحواشـي، والاختصار والترميز وغير ذلك6.

ومع معرفة الطباعة صار كثير من الناس ينسخون بعض المخطوطات بما فيها من تصـيفات وتحريفات7 ويدفعونها للمطبعة وينشرونها، وإذا كان هذا الأمر كان له مبرره قديما فليس مستساغا ولا مقبولا اليوم، فالاعتماد على كتاب مصحَّف ومحرَّف لن ينتج عنه إلا فكر سقيم وأحكام خاطئة. 
لذذا عنـي العلمـاء بتحقيتق النصـوص تحقيقًا منهجيَّا، وألفـت في قواعده ومناهجـاه مؤلفات عديدة بهدف مساعدة من يتصدى لتحقيق نص تراثي على إخـراج عمـل يوثق بـه. وبهـا صـار التحقيق فنَّا لـه أصـوله وقواعده، وحـدوده وأسـاليبه ومناهجـه، وأدواتـه التي تسـهم في إخـراج النَّص للمتلقي في صـورة صحيحة بعيدةٍ عن العشوائية والاجتهاد الخاطئ المضلِّل. مفهوم التحقيق: التحقيق: قراءة النَّص على الوجه الذي أراده عليه مؤلفه، أو على وجه أقرب ما يكون إلى ما تركه المؤلف. ويَجمع الأستاذ عبد السلام هارون عناصر التحقيق في صحةِ العنوان واسمِ المؤلف، ونسبة الكتاب إلى مؤلّفها، وإخراج متن الكتاب قريبًا من نَصِّ المؤلف 8 وللتحقيق خطواتُ مرتَّبة ترتيبًا دقيقًا لا يصح فيها تقديم متأخر ، ولا تجاوز بعضـها، وإلا وقع المحقق في مشـاكل من شـأنها ضسياع الوقت والجهد وفسـاد النَّص.

وليس كل إنسان مهينًا لخوض غمـار هذا العمل المرهق، فلمحقق الجيد صفاتُ يجب أن يتوافر فيـه كثير منها، كالصسبر والأمانـة والجَلَدِ، والثـك في النفس لا في النَّص، والإمام بمصطلحات الفن الذي يسلك دَرْبَ تحقيقه، والعلح بأنواع الخطوط، ومنـاهج المحققين، والدرايـِة بأسـاليب النَُّّاخ، والإحاطـةِ بقسط وافر من قواعد علوم النحو والصرف والعَروض وقواعد الإمـلاء الحديث، ومعرفةِِ مصادر التحقيق العامة والمتخصصة... الخ. 
وسأحاول في هذه العُجالة ذكرَ خطوات التحقيق مرتبةً ليسلك المحقق هذا

$$
\text { الدرب بيسر وسهولة. }
$$

\section{أولا: اختيار النص ومصادر المعرفة بالتراث:}

إن اختيار النَّص المناسب لفكر المحقق وثقافته أمر غير هيّن؛ وذلك لكثرة العناوين في كل فن، وتفاوتِها في القيمة العلمية، ووفرة النسخ حينًا وندرتها حينًا، وصعوبةٍ الحصول عليها أحيانًا، والتأكدِ من خلوها من موانع تحقيقها؛ لذا يجب على المحقَّق الإفادة مما يأتي عند بحثه عن النِّص المقصود ليتمكن من جمع عدد من النسخ يساعده في إخراج النَّص في أقرب صورة تركها المؤلف: ا-كتاب تاريخ الأدب العربي لبروكلمان، ط: دار المعارف.

ب-كتاب تاريخ التراث العربي لفؤاد سزكين، ط: جامعة الإمام محمد بن سعود.

ج-كتاب تاريخ آداب اللغة العربية لجرجي زيدان، ط: دار الهلال. د-فهارس المكتبات التي تُعنَى بحفظ المخطوطات.

هـ-معجم تاريخ التراث الإسـلامي في مكتبات العالم، لعلي الرضـا قرة، ط:

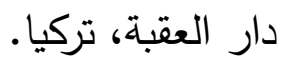

و -المجلات والدوريات التي تُُنَى بالمخطوطات كمجلة معهد المخطوطات العربية، ومجلة المورد العراقية، وغيرها . ز -خِزانـةالتراث: وهـي قاعـدة بيانـات تعـرِف بالمخطوطـات العربيـة في المكتبات، أنشأها مركز الملك فيصل. ح-قاعدة بيانات مركز جمعة الماجد للثقافة والتراث. 
ط- دليل الباحث في التراث العربي لبسَّام الجبلي، دار البصائر • ي - مراجعـة الكتب التي تهتم بأسـماء الكتب والمؤلفين، ككشف الظــون لحاجي خليفة، دار إحياء التراث العربي. ك- كتب المشيخات والأثنَات.

ل سؤال أهل العلم الْمُلِيّين بحركة المخطوطات فهرسةً وتحقيقًا ونشرًا.

\section{ثانيًا: ما يشترط في النص المراد تحقيقه:}

ليس كل نص يحظى به راغب التحقيق صالحا لأن يحقق، بل هناك ضوابط لابد من مراعاتها، حتى لا يقدح في عمله، ومن هذه الضوابط:

1-ألا يكون النَّص قد سبق تحقيقه تحقيقًا علميَّا، أو طُبع طبعة متقنة أقامت النَّصَ واستوفت أركان التحقيق.

ب-أن تكون للنص أكثر من نسخة خَطِيَّة، ليتمكن المحقِق من إقامة النص ومعالجة ما به من تصحيفات وتحريفات وسقُط أو اضطراب، ويستثنى من ذلك النُّنخ التي بخط مؤلفيها، أو اليتيمة التي أخت لها وتتسم بتمام النص وقلة التصحيفات والتحريفات. ج-أن يكون المخطوط ذا قيمة علمية وتاريخية، ويقدَّم هنا الأهمُ على المهم، والأصولُ على الفروع. د-إذا كان الكتاب قد نُشر نشرة معيبة بسبب أوهام وقع فيها المحقِّق، أو لخطئه في تحقيق العنوان ونسبة الكتاب لمؤلفه، أو لعدم أمانته بتدخله في 


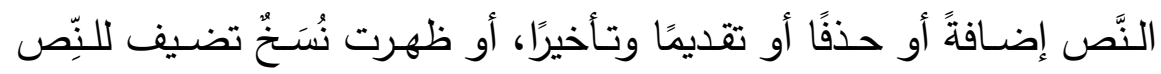
ميزة، أو طُبع الكتاب بدون مكمِّلات التحقيق.

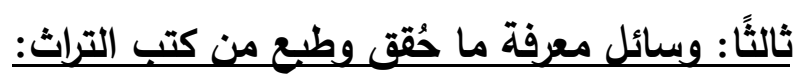

على الححقق بذل الجهد للتأكد من عدم تحقيق النص تحقيقا منهجيا، حتى لا تهدر الجهود، والوقت والمال في عمل لن يضيف جديدا، ومما يستعين به في ذلك:

ا-كتفاء القنوع بما هو مطبوع، لإدوارد فنديك . ب-معجم المطبوعات العربية، ليوسف إليان سركيس، مطبعة سركيس.

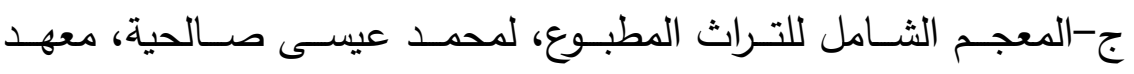

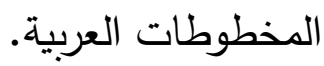
د-النشرة المصرية للمطبوعات. يصدرها قسم الإيداع بدار الكتب المصرية. هـ-معجم المؤلفين، لعمر رضا كحالة، مؤسسة الرسالة. و -الكتب العربية التي نُشرت في مصر بين 1936-1940، لعائدة إبراهيم

ز زقوائم الرسائل العلمية المحقَّة في بعض الكليات والمعاهد. ح-الأعلام للزركلي، دار العلم للملايين.

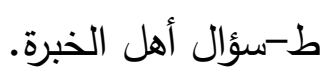

\section{لريعًا: جمع النسخ ودراستها:}

إذا تيقن الدحقق أن النص الذي بين يديه لم يسبق تحقيقه تحقيقا منهجيا، أو

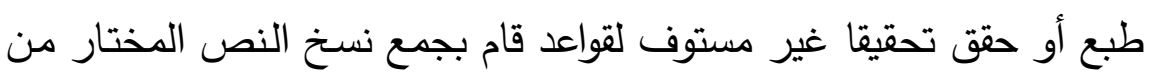


مظانها، وليس لـه أن يتساهل بالاكتقاء بمخطوطتين مع علمه بوجود نسخ أخرى، فقد تكون النسخ الأخرى أولى بالاعتمـاد عليها، وإذا مـا انتهى من جمع النسخ قام بدراستها دراسة متأنية تعينه على ترتيبها ترتيبا منهجيا. خامسًا: دراسة النُّنَخْ:

بعد جمـع النَّنَخ يتفحص المحقِّق مـا جمعها، ثم يقوم بقراءتها قراءة متأنية ودراستها للوقوف على تمامها ومنازلها ودرجاتها، ثم يرتبها وفق الضوابط الآتية محددًا الأم أو الأصل 9 الذي سيقوم بنسخه، مرتبًّّا المساعِدات حسب درجاتها، مفيدًا في ذلك من دراسة نوع الورق (إن عاين المخطوط) والْمِداد والخط وتاريخ النَّسخ، وما يوجد بها من قيود وإشـارات علمية وتاريخية، ثم يسمِّي النَّسخ باسم البلد أو الحَرف الأول مـن المكتبـة التي تحـتفظ بالنسـخة، أو يختار لها رمـزًا يميزها، ويجب على المحقِق التأكد من تاريخ النَّستخ حتى لا يقع في وهم قِدَم النُّــة، ودراسـة مـا يـرد في قيــ الفـراغ 10 مـن تواريخ ليتمكن مـن رسم شـرة المخطوطة رسمًا صحيحًا، وليستطيع تقدير عمر المخطوطة تقديرًا سليمًا. ويمكن للمحق عمل جدول يتضمن أهم سمات النُّنخ، ويمنح كل سمة منها درجـة، وعلى ضـوء مجموع الدرجات يقوم بترتيب النسـخ، وهذا نمـوذج يمكن الإضافة إليه أو الحذف منه حسب ظروف كل عمل:

\begin{tabular}{|c|c|c|c|c|c|c|c|c|c|}
\hline الارجات & مضبوط & مطبوع & محقق & تص/تد & الصحة & التمام & المؤلف & العنوان & \\
\hline 54 & 7 & 0 & 0 & 7 & 10 & 10 & 10 & 10 & نسخة أ \\
\hline 43 & 0 & 0 & 0 & 5 & 10 & 8 & 10 & 10 & نسخة ب \\
\hline 42 & 9 & o & 0 & 8 & 10 & 5 & 0 & 10 & نسخة ج \\
\hline
\end{tabular}


وعلي المحقـق الوقـوف على سـمات الناسـخ، وخصــائص رســه للنص، ومنهجه في الإشارة إلى الإحاق، والتقديم والتأخير ، والاختصارات والرموز التي تقابله، وسأبين أهم هذه السمات مدعومة بنماذج من المخطوطات .

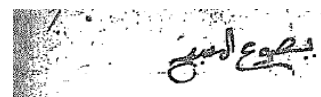

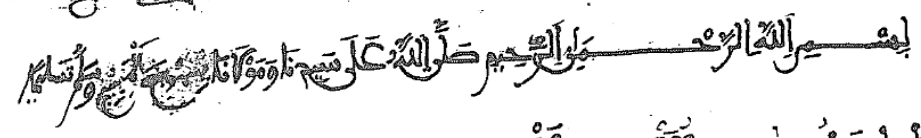

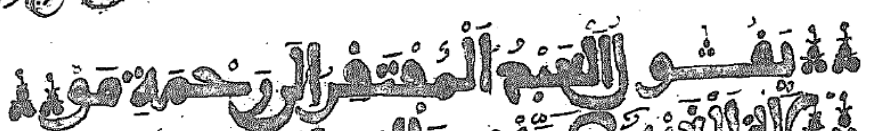

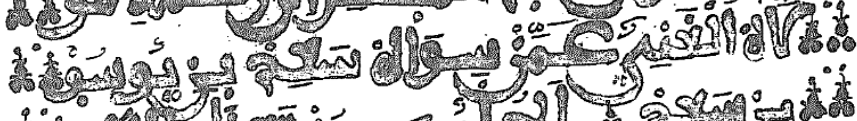

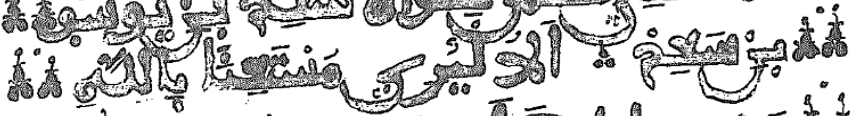
:

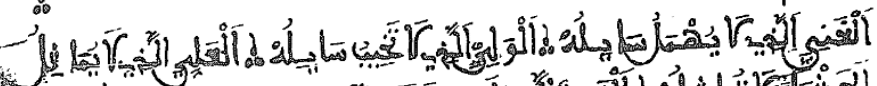

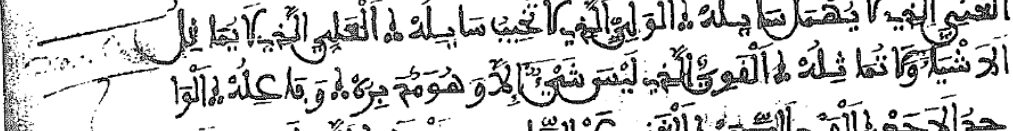
$\therefore$ ح...

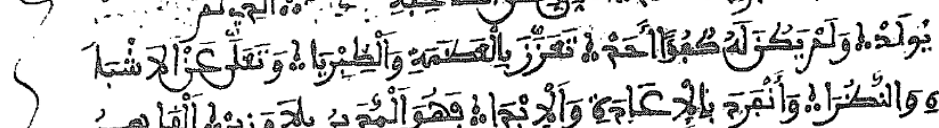

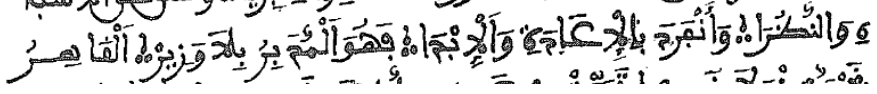

نموذج لخط مغربي ترسم بعض حروفه بطريقة تخالف المعتاد:

$$
\begin{aligned}
& \text { القاف : رسمت بنقطة واحدة من أعلى (يفول). } \\
& \text { الفاء: رسمت بنقطة واحدة من أسفل . } \\
& \text { الدال: ترسم شبيهة بالميم • }
\end{aligned}
$$

استكمال الكلمة في السطر التالي: (مولاه ،الواحد). 


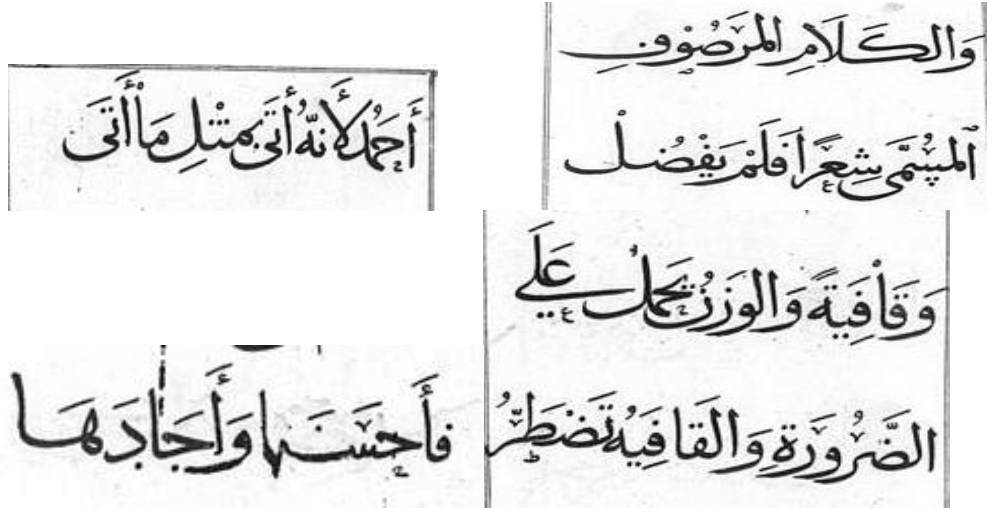

ميز الناسخ الحروف المهملة:( الصاد والحاد والعين والطاء) بحروف صغيرة من جنسها أسفلها، وفرق بين السين والثين بثلاث نقاط تحت السين، والدال بنقطة واحدة تحتها. رموز وردت في بعض المخطوطات:

استخدم النسَّاخ قديمًا الكثير من الرموز لمعالجة مـا يصـادفهم من مواقف ر اقف أثناء نساختهم، وصـار بعضـها كالمصطلح عليه بينهم، وربما استخدم بعضهم رمزًا لم يسبق به، وربما خالف لاحق سابقا، بل لا نتجاوز الصواب إن قلنا: إن تصرفات كثير من النساخ تقتضيها ظروف العمل الذي بين أيديهح • ومعرفة المحقق هذه الرموز ييسر له فهم أمور كثيرة أبسطها التثريق بين ما هـو مـن صـلب المـتن ومـا أقحـم عليـه، وترتيـب الــص، وتصـويب أخطائهه، واستدرالك ساقطه... الخ، ومن هذه الرموز : حرفا الميم ( مـ ... مـ ): 
وضعهما أحد النساخ على كلمتين حدث فيهما تقديم وتأخير خلافا للأصل،

$$
\begin{aligned}
& \text { وكأنهما اختصار لقوله " مقدم ومؤخر أو العكس ". }
\end{aligned}
$$

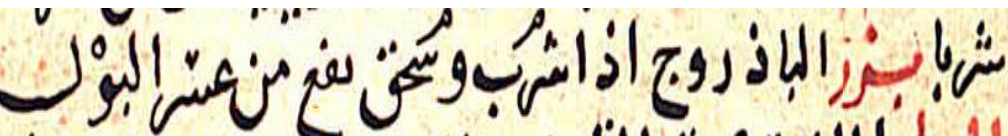

$$
\begin{aligned}
& \text { علامة الإحالة أو الإلحاق: }
\end{aligned}
$$

وهي عبارة عن خط رأسي مائل جهة استدراك السقط، و ويلجأ الناسخ لهذه

الطريقة حتى لا يقحم السقط بين السطور إذا كانت المسافة بين السطور ضيقة فيشـوه جمـال الصـفحة، ويكون مكانسه هـامش الصـفحة الأعلى أو الأيمـن أو الأيسر ، ويكتب آخره ( صح ) تمييزًا له عن التعليقات والثروح.

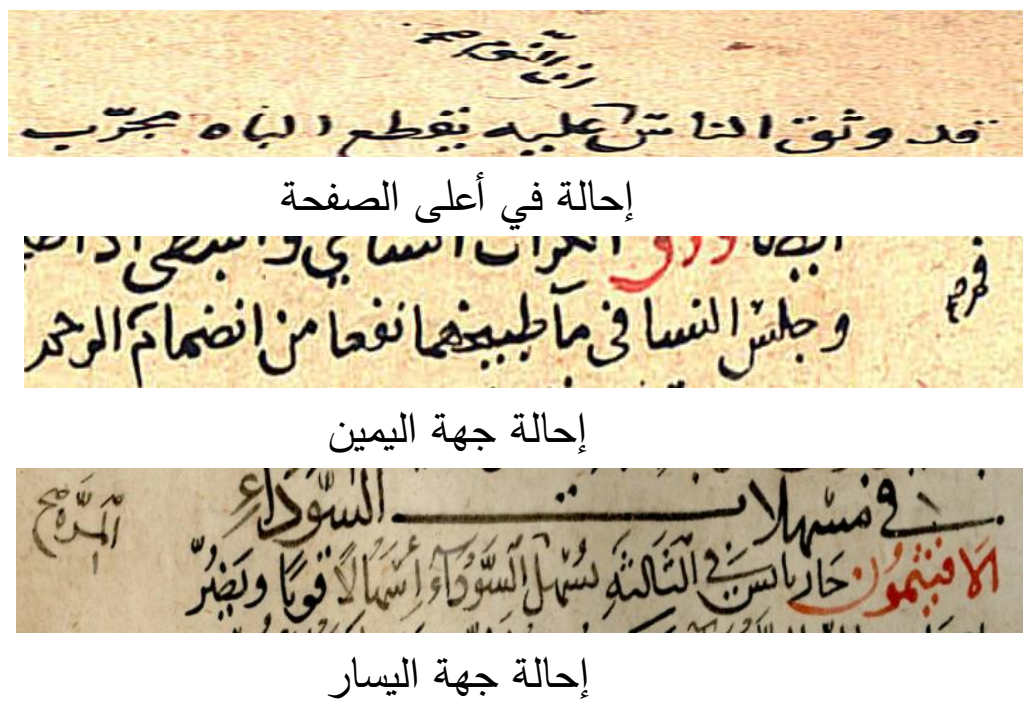

أما إذا كانت المسافة بين السطور واسعة، فبعض النساخ يستدرك السقط

فوق موضعه ويلحقه بحرف ص، وقد يستدركه تحت موضعه . 


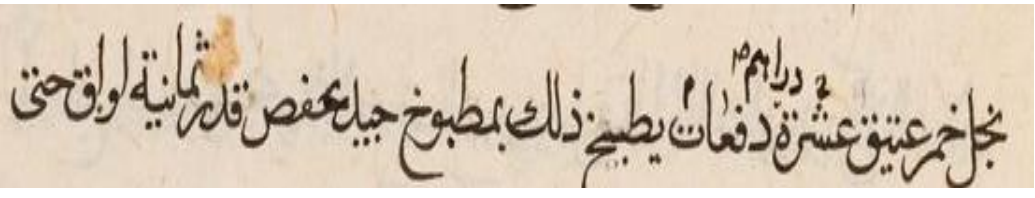

استدراك السقط فوق موضع السقط

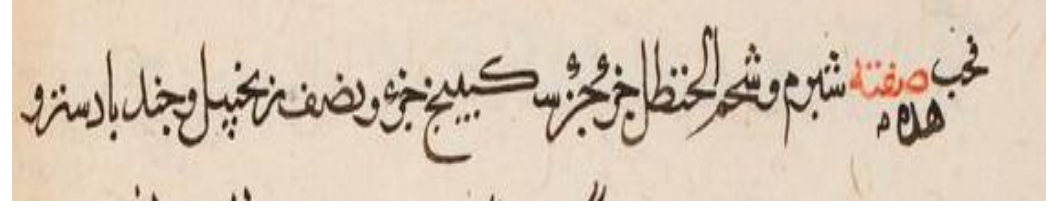

استدراك تحت موضع السقط

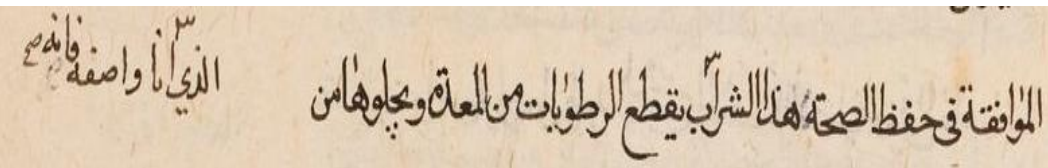
علامة إحالة تشبه رقم 3

(التعليقات:

ترد على حواشي كثير من المخطوطات تعليقات مصدرها الناسخ أو المتملك أو القـارئ، وتختم في الغالب بالإشـارة إلىى مصـدر التعليق، كقولـه (قـاموس)، ويغرق بينها وبين الإحالة بعدم وجود علامة إحالة لها، وبأنها غير مردفة بكلمة ( صح )غالباً، وأحيانًا يوصل بين التعليق أو الشرح والمشروح بخط مستقيم .

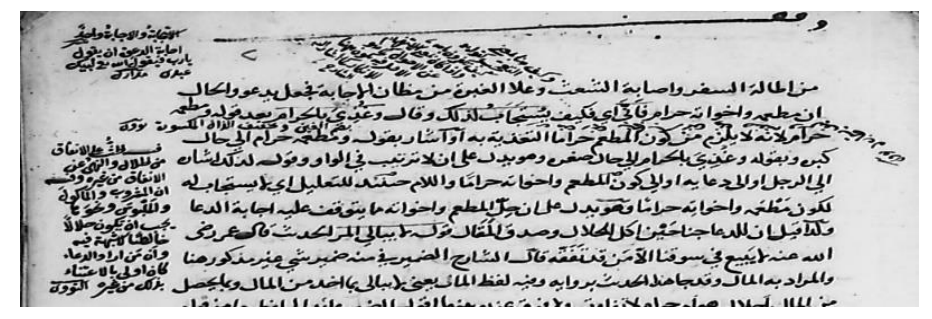

جاءت التعليقات في الهوامش مردفة بذكر مصدر المعلومة (الشارح،

$$
\text { النووي، مدارك) }
$$


الدارة المنقوطة:

وهي عبارة عن دائرة تتوسطها نقطة استخدمها الناسخ في إحدى نسخ كتاب

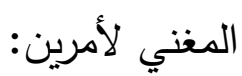

الأول: كالنقطـة الحديثة في نهايـة الجُمل والفِقرات، وفيهـا تكون مفردة لا

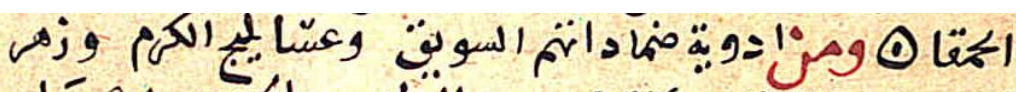

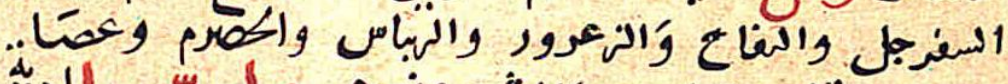

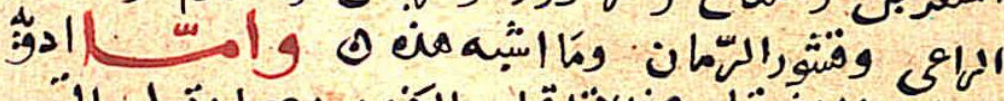

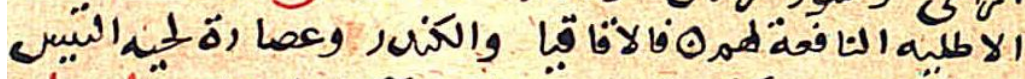

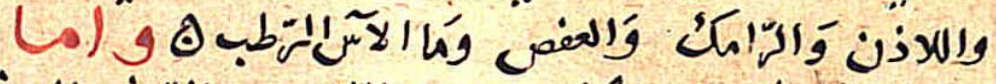

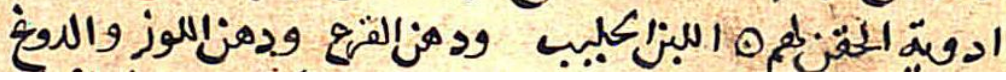

الثاني: في نهاية كلام انتهى في وسط السطر ، ومع العناوين التي تتوسطه،

فيكرر الدارة في موضع الفراغ حتى لا يضيف أحد فيه شيئا.

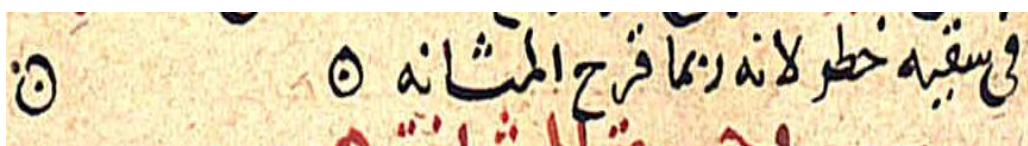
(4) winlas

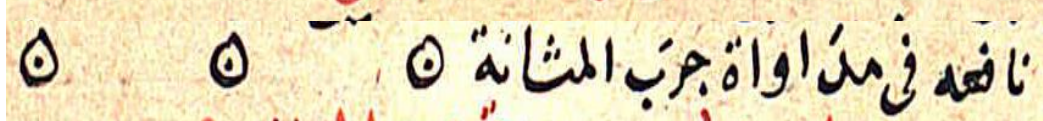

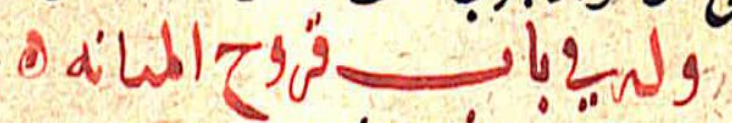

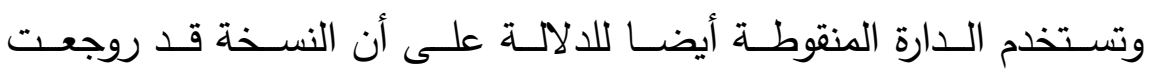




\section{تصوبب الكلمة:

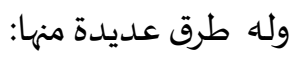

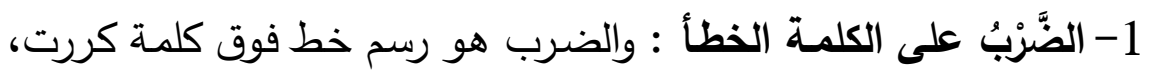

أوكتبت على غير وجهها، وهو أجود عند العلماء من الكثط والمحو، وللضرب

صور عديدة منها هذه الحالة.
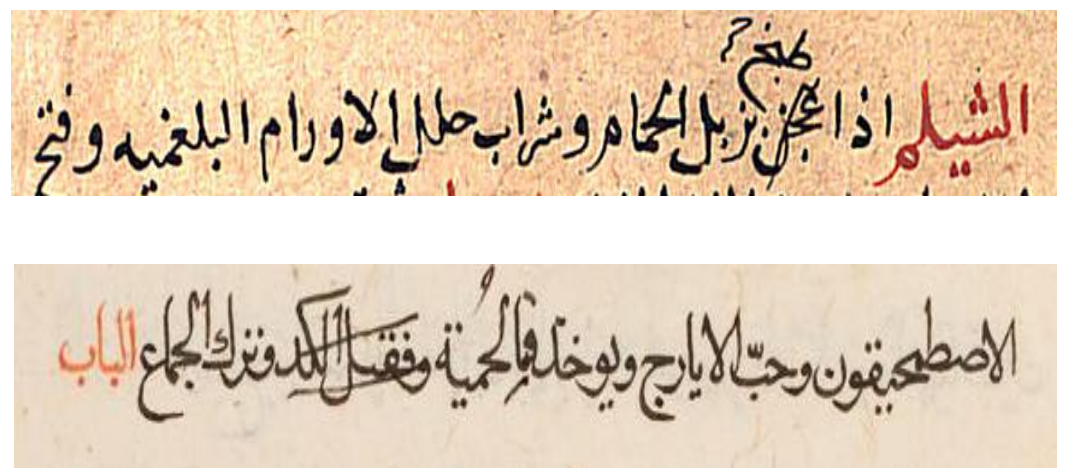

\section{2- التصويب دون ضرب على الخطأ:}

ومنه ما جاء في إحدى مخطوطات المغني لابن البيطار حيث بقيت الكلمة الخطـأ على حالهـا؛ لأنهـا عنـوان مـــل جديـد مـع وضـع علامـة تشـبه رقم (2)فوقها، وكتب الصواب في الهامش تعلوه العلامة نفسها.

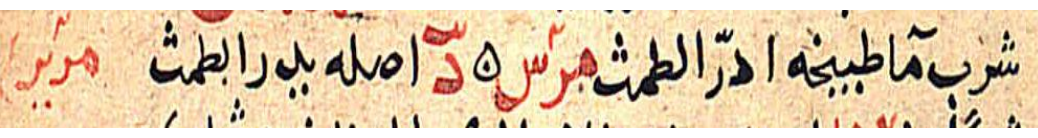

\section{تكملة الكلمة:}

حرص النساخ على أن تكون نهايات السطور متماثلة محافظةًة على جمالها، ولكن أحيانًا تكون الكلمة الأخيرة في السطر طويلة، فيلجأ الناسـخ إلى زحزحة

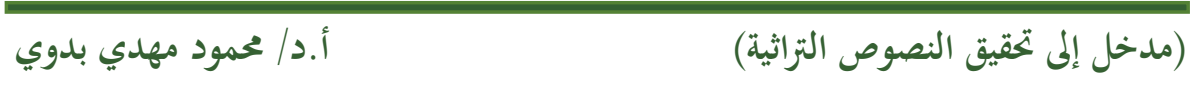


جزء من الكلمة في الهامش, أو مَطِّ الحرف، وأحيانًا يكمل الكلمة في السطر التالي

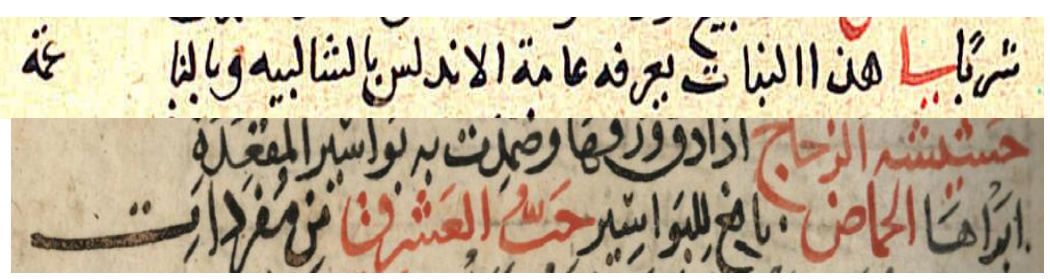

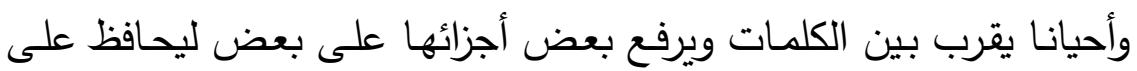

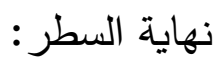

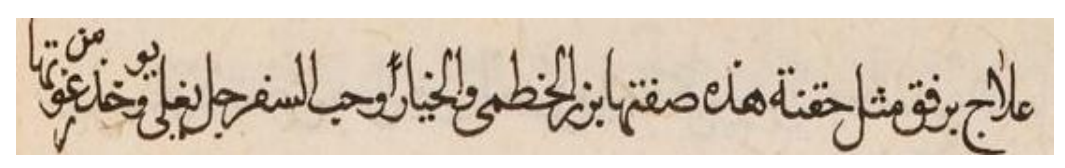

الاختصار والريز

يلجأ كثير من المؤلفين والنساخ إلى اختصار الأسماء التي يكثر تكرارها، وفي هذين النموذجين اختصر اسم جالينوس في حرف "الجيم" تعلوه علامـة تثبه الثدة، وفي النموذج الثاني "الدال" اختصار لاسم ديسقوريدوس أيضًا.

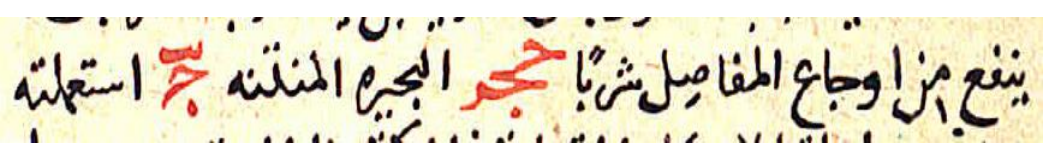
*** 


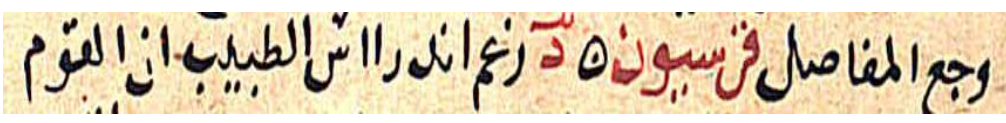

وتشيع في كتب الحديث النبوي وكتب اللغة الرموز والاختصارات:

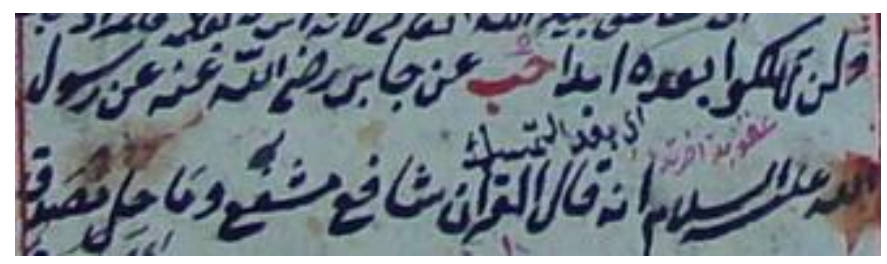

$$
\text { حب = ابن حبان }
$$

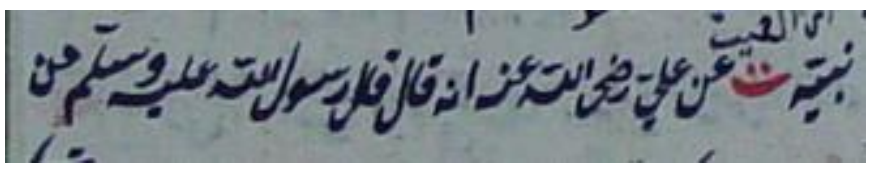

$$
\text { ت = الترمذي }
$$

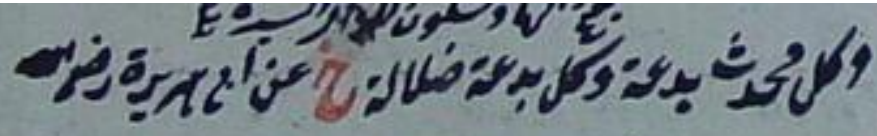

$$
\text { خ= البخاري }
$$

\section{كتابة بعض الكلمات بصور خاصة:}

ir رسم كلمة " أيضًا " بألف قصيرة مقلوبة:

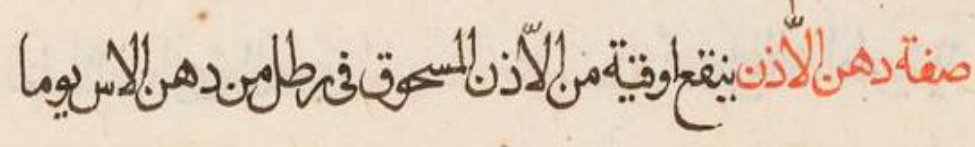

$$
\text { تضعيف اللام بشدة فوقها: }
$$

خان 
رسم الكاف المتوسطة كاللام المائلة يسارًا :

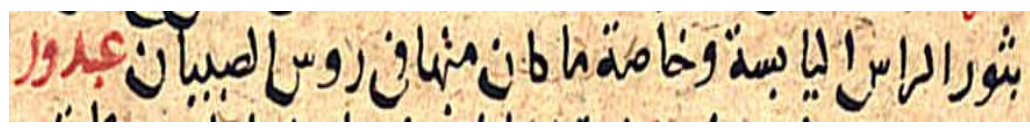

$$
\begin{aligned}
& \text { حذف طرف الكاف في الابتداء }
\end{aligned}
$$

***

سادسا: قواعد ترتيب النستخ:

على المحقق أن يعني بقيد الفراغ11، فكثيرا مـا يحتوي على معلومات تفصـح عن الناسـخ، ومصـدر نسخته، وتـاريخ النسـخ، وغير ذلك مـن المعلومـات التـي تسـاعد المحقـق على ترتيـب النسـخخ حسب قيمتهـا ومنزلتها، ومن هذه القواعد:

1-النسخة الأم: وهي نسخة المؤلف (المبيَّضة الأخيرة¹) التي كتبها بيده .

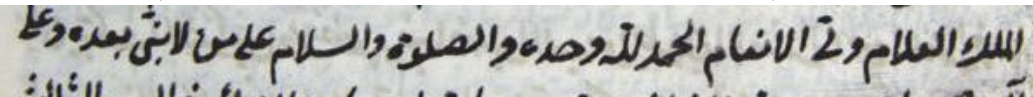

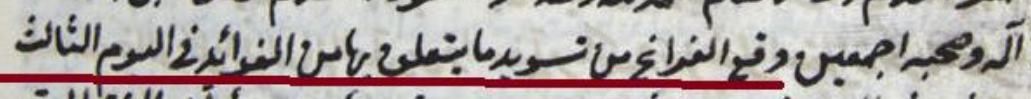

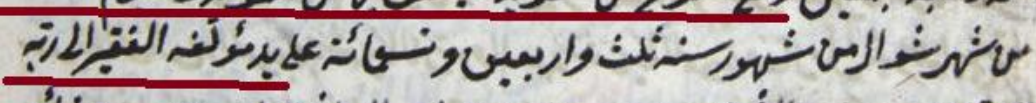

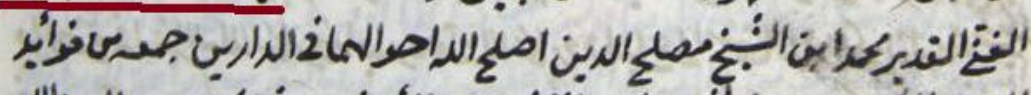

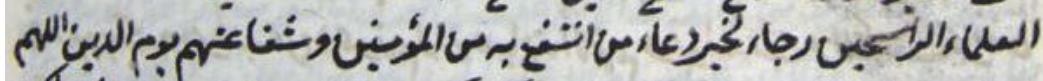

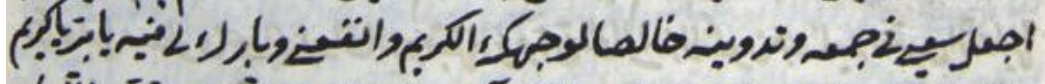

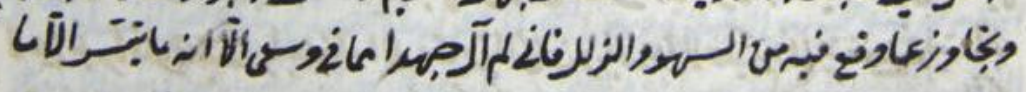

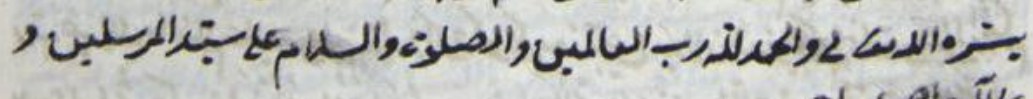

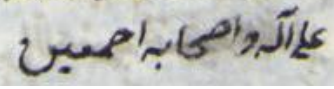

حاشية شيخ زاده بخط مؤلفها

أ.د / حممود مهدي بدوي

(مدخل إلى تحقيق النصوص التراثية) 
ب-مسوَّدة 13 المؤلف التي ضساعت مبيَََّتُها، أو لم تبِيض.ومنها مسودة رسالة "مزيل نقاب الخفا عن كنى سـاداتنا بني الوفا" حيثت تركها مرتضى الزبيدى دون تبييض 14

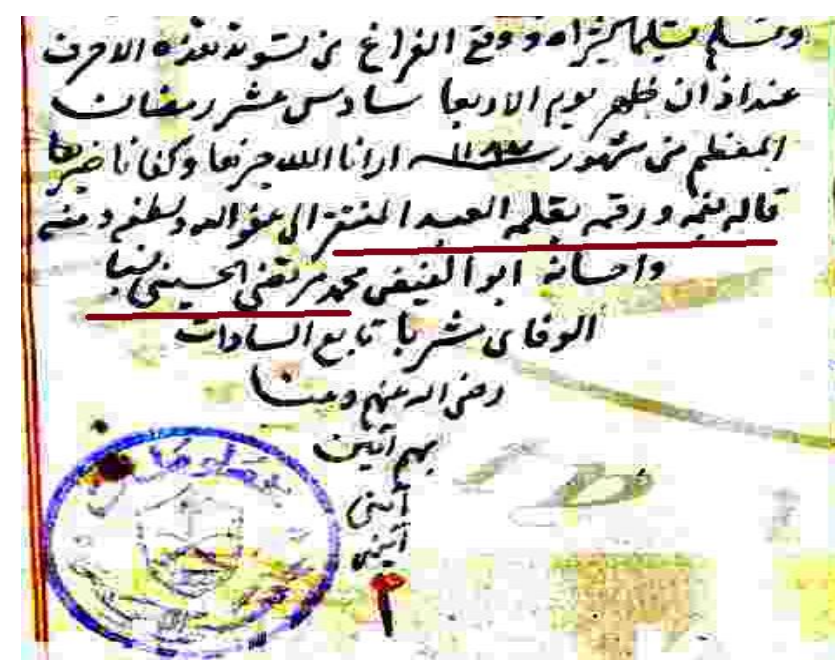

ج-النسخة المنقولة عن نسخة المؤلف، وقُرئت عليه وأجازها.

د- النسخة المنقولة عن نسخة المؤلف وقوبلت عليها من غير إجازة.

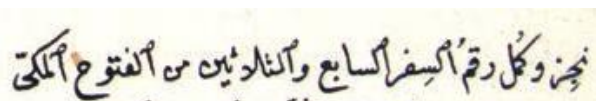

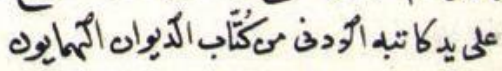

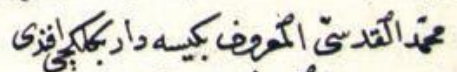

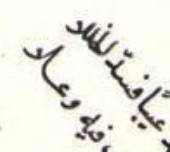

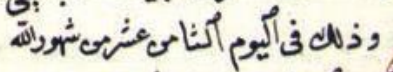

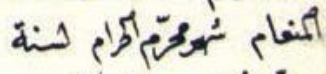

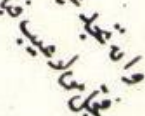
|

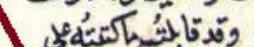

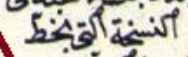

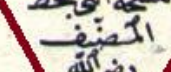
ass

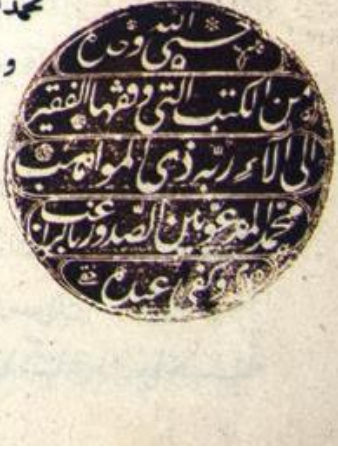


هـ-النسخة المكتوبة في عصر المؤلف وعليها سماعات.

و -النسخة المنقولة عن نسخة المؤلف وعليها الروايات المسندة.

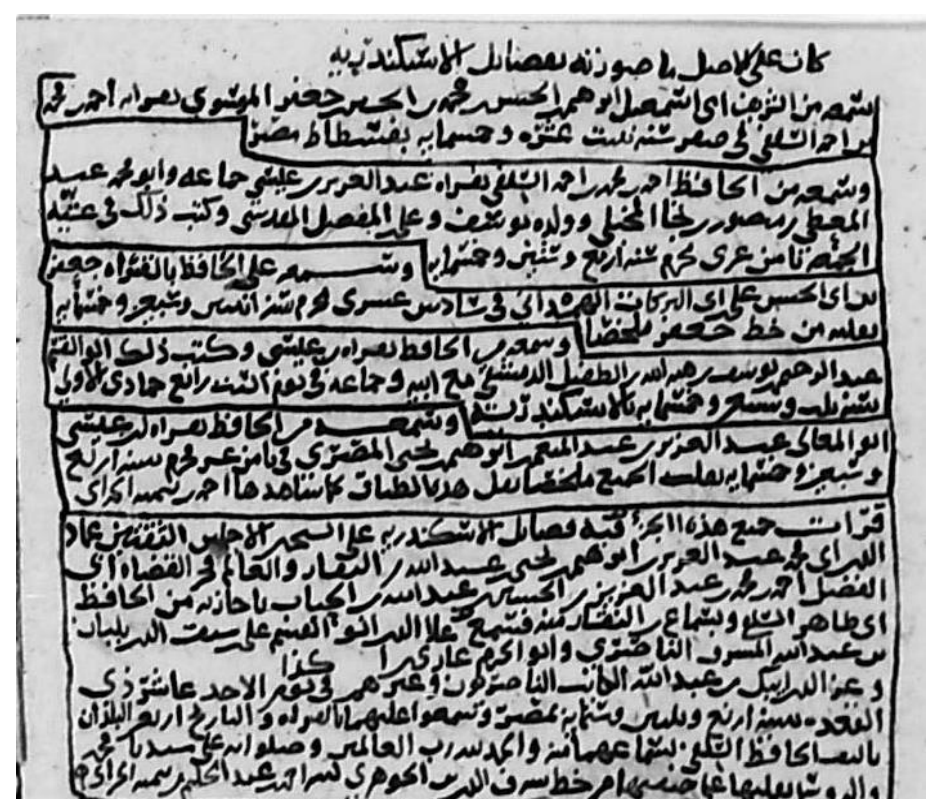

ز -النسخة المكتوبة في عصر المؤلف وليس عليها سماعات.

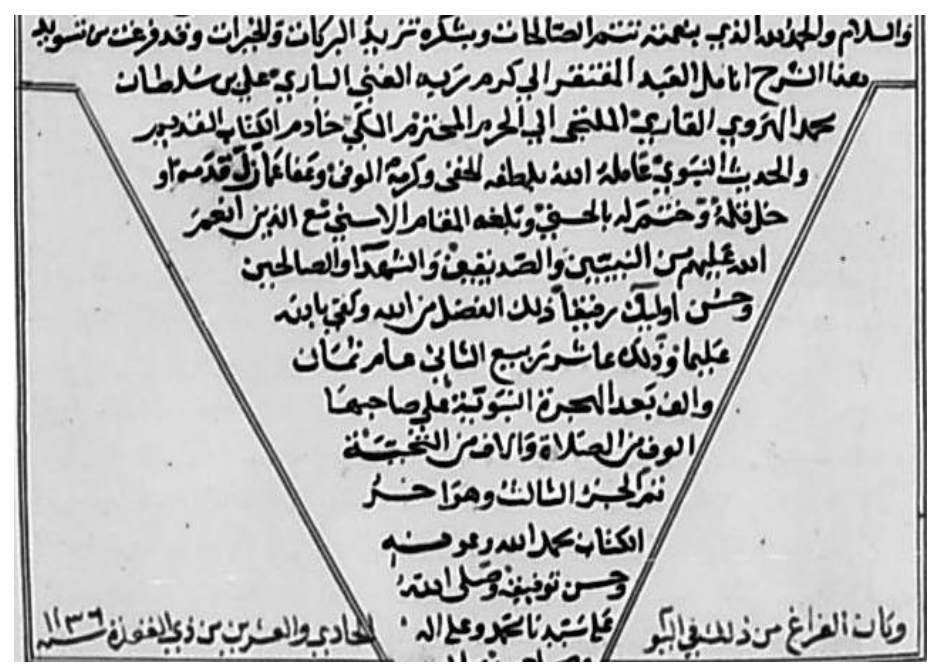

أ.د / محمود مهدي بدوي

(مدخل إلى تحقيق النصوص التراثية) 
نموذج يبين تاريخ فراغ المؤلف من تسويد نسخته وهو (10 من ربيع الثاني 1008 هـ )، ثم تاريخ فرعها وهو (21 من ذي القعدة سنة 1136هـ)، كما أفاد قيد الفراغ أن هذه النسخة منقولة عن نسخة المؤلف. ح-النسخة المتأخرة عن عصر المؤلف، ولكنها نقلت عن الأصل .

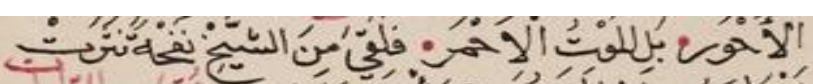

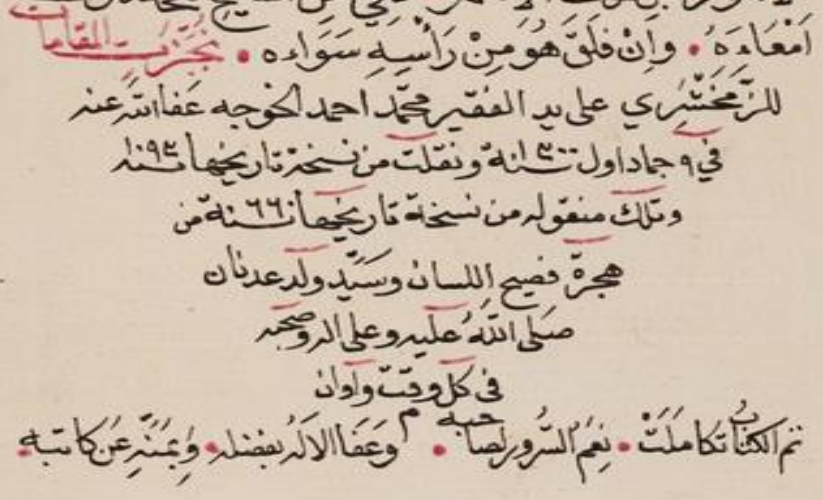

ط-النسخة المتأخرة عن عصر المؤلف، لكن ناسخها عالم مشهور بالدقة والأمانة.

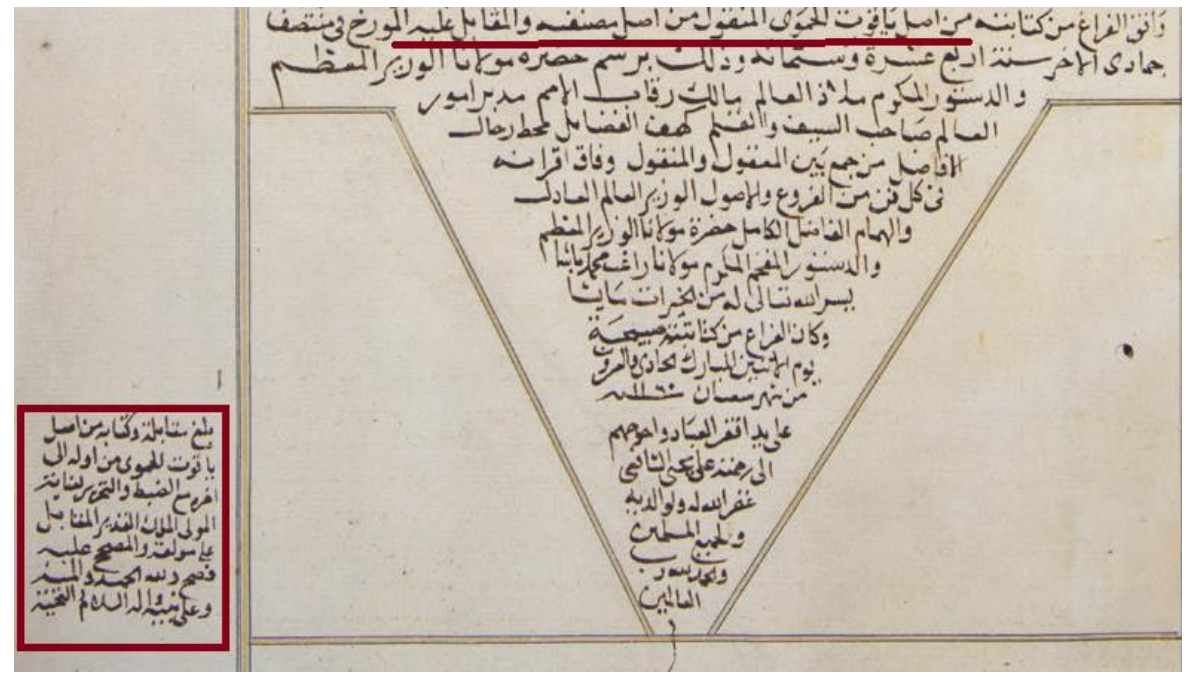

$$
\text { أ.د / محمود مهدي بدوي }
$$

(مدخل إلى تحقيق النصوص التراثية) 
ي - النسخة المتأخرة التامة القليلة التصحيف . ك- النسخة المؤرَّخة تقدم على غير المؤرخَّة عند تمامهما .

\section{تنبيه:}

• عند الحصول على نسخة المؤلف وتبين أنها مبتورة أو متآكلة بحيث يصعب على المحقق قراءتها، تُقََّّم عليها النسخة التالية في الترتيب؛ لتكون أصلا للتحقيق، وتنزل نسخة المؤلف إلى درجة الفروع. على المحقِق التأكد من تاريخ النَّنخ، وذلك بمطابقة نوع الخط والْمِدَداد والورق، فقد دأب بعض النَُّّاخ على نقل تاريخ النسخة المنقول عنها دون الإشارة لذلك.

\section{سابعًا: النَّستخ والمقابلة:}

كان للعلماء قبل ظهور الحاسوب طرقٌ يستخدمونها في نسخ الأصل، واليوم صار الاعتماد على الحاسوب كبيرًا لسهولة الحذف والإضافة والتبديل وعمل . الحواشي والرموز؛ لذا فسأقتصر على هذه الطريقة الأكثر استعمالا. قبل نَسخ المخطوطة المختارة أصلا للتحقيق على المحقِق أن يقرأها قراءة متأنية ليعي مضمونها وأسلوب المؤلف ومنهج الناسخ في رسم الكلمات وبعض الحروف، وليتعرف على دلالات رموزها، ثم يقوم بنسخها كما هي دون تصويب أو تعديل على وفق قواعد الإملاء الحديثة، مرقًِّا صفحاتها بأي من الطرق المستعملة في ترقيم أوراق المخطوط15، وبعد الانتهاء منها 
يقوم بمراجعتها ليتدارك ما قد يقع منه من سهو نتيجة خطأ في الإملاء أو

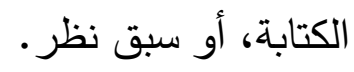

• ثم يقوم بمقابلة النص المنسوخ بالمساعدات واحدة تلو الأخرى حسب

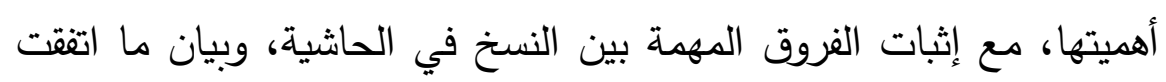

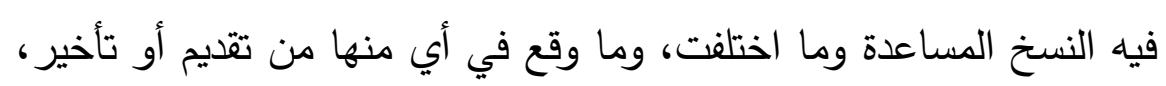
وما اختاره من قراءات النُّخخ المساعدة معلِّلا لاختياره .

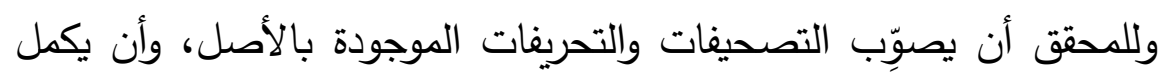
نقص الأصل من المساعدات بعد التأكد من هذه الزيادة، وأنها ضرورية

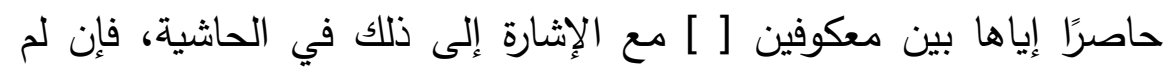
يتأكد، أو كانت الزيادة غير ضرورية ذكرها في الحاشية منسوبة لنسختها.

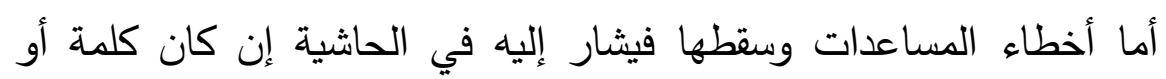

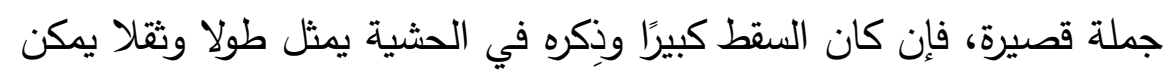
حصره بنجمتين مثلا والإشارة إليه في الحاشية . إذا كان النَّص مضبوطًا بالثنكل أثبتَّ المحقِّق الضبط. 


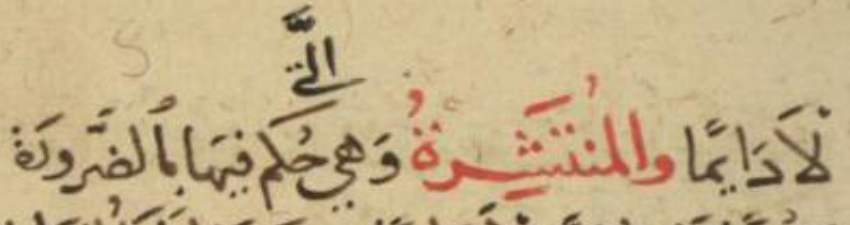

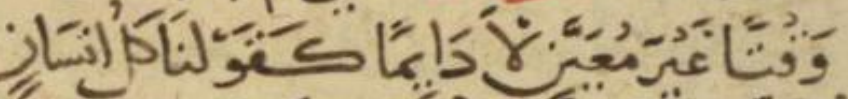 \\ (1) \\ 每

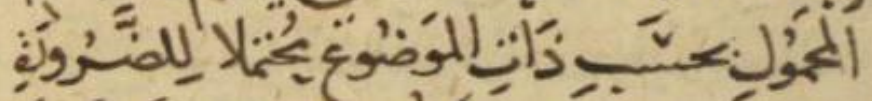

الفروق البسيطة المتكررة للمحقق تصويبها دون الإشارة إليها في الحاشية حتى لا يثقلها، مع إشارته لذلك في منهج تحقيقه، مثل صلى الله عليه وسلم، وعليه السلام ، وقال وفال.

• على المحقِق أن يتنبه لرسم الآيات القرآنية التي قد ترد بقراءة شاذة، أو قراءة اعتمد عليها المؤلف تتاسب عصره وبلده، أو لحديث أو بيت شعر برواية مختلفة، فلا يتعجل في تخطئة النَّص، بل يتريث حتى يتأكد من المصادر المختلفة.

• يضبط المحقِق الآياتِ القرآنيةَ، والأحاديثَ النبويةَ، والأشعارَ، والأعلامَ، والكلماتِ الصعبةَ، وما أشكل. • إذا لم يكن المؤلف قد وضع عناوين لموضوعات كتابه، فيجوز للمحقِق إضافة عناوين رئيسية أو جانبية محصورة بين معكوفين. 
• • في مخطوطات التراجم تُخرَّج الأعلام المترجَم لها إلى وسط السطر

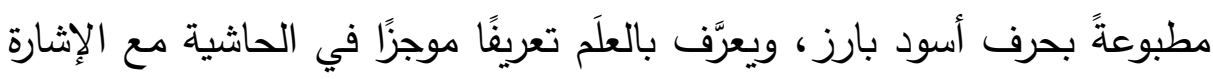
إلى بعض المصادر المتخصصة التي ترجمت له. • إذا كان بالنَّص شعر لا فاصل بين شطريه، فَصَلَ المحقِّق بينهما، وبَيَّن في الحاشية ما قد يعترى بعض الأبيات من اضطراب في الوزن، أو تبديل لبعض الكلمات، إلا إذا كانت الأبيات مُدوَّة.

الكتب الثارحة التي تثتمل على متن وشرح، يميز المحقق بين المتن

$$
\text { والشرح بما يراه موفيا بالغرض. }
$$

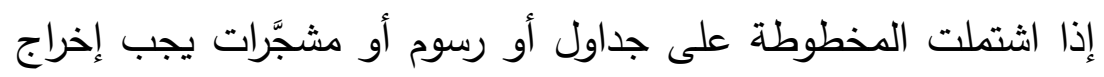

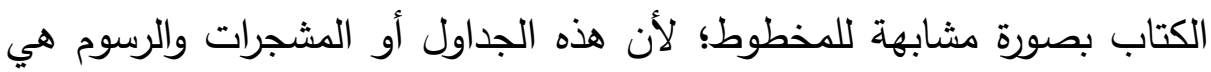
جزء من النّص، وإهمال المحقق لها يعد خلا بالنص وقدحًا في منهجج التحقيق.

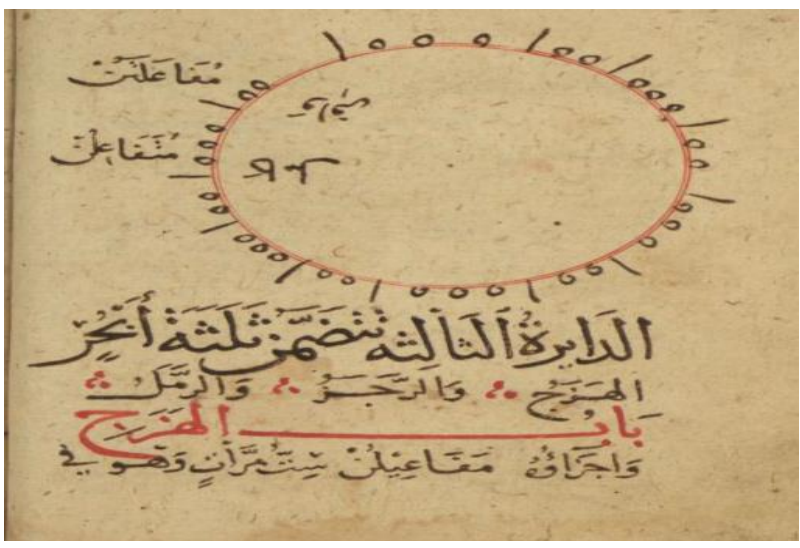

ترسم الدائرة العروضية وأثباهها في موضعها من النص 


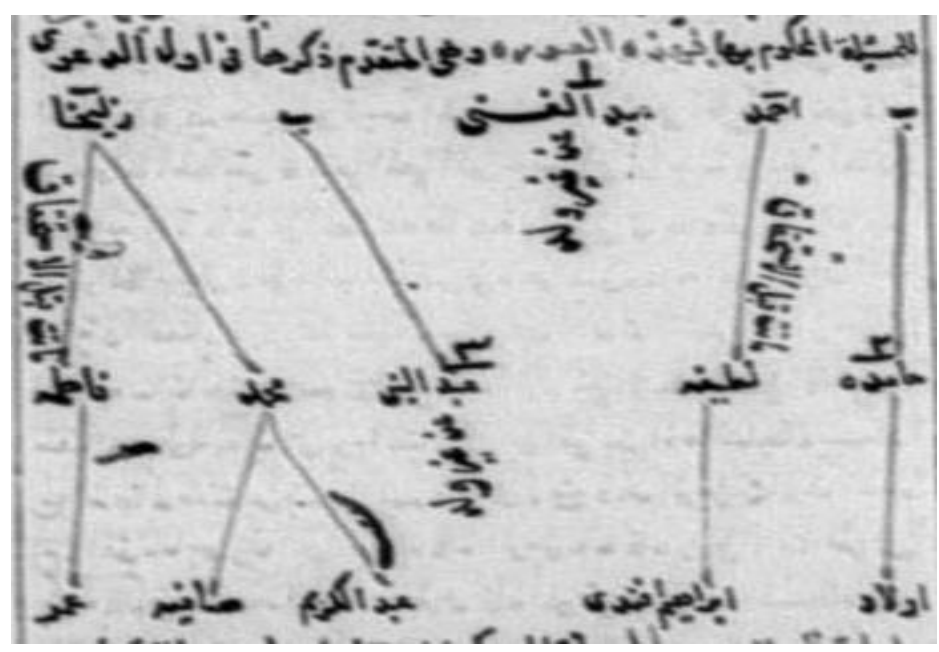

ترسم مثل هذه المشجرة كما جاءت في المخطوطة

• على المحقق عزو ما يرد في النَّص من آيات قرآنية، بذكر اسم السورة ورقم الآية حاصرًا الآيات القرآنية بين قوسين مزهرين النبوية، وتحصر بين علامتي تتصيص " "، ويتم العزو أو التخريج بذكر الكتاب والباب والحكم على الحديث، أما الألفاظ اللُّغوية فيذكر المصدر والمادة، وتخرَج الأعلام غير المشهوة من كتب التراجم المتخصصة، والأماكن والبلدان من مصادرها.

• تخريج المصطلحات العلمية الواردة في النص تخريجًا موجزًا مع الإشارة

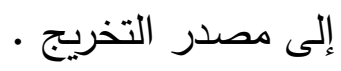
• تخريج النصوص الواردة في النَّص بإحالتها إلى مصادرها(كتب مؤلفيها أولا، ثم المصادر الأخرى عند عدم وجودها)، وتقدم المصادر المحققة على غيرها، مع ذكر بيانات المصدر إن كان مطبوعًا، ورقم المخطوط ومكان حفظه

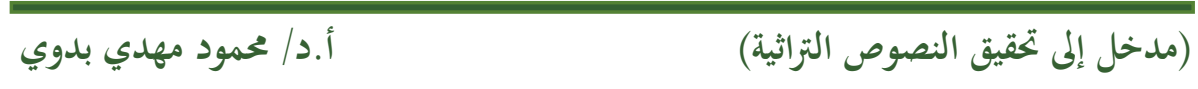


ورقم اللوحة إن كان مخطوطًا، وإذا عرفنا أن التخريج يهذف إلى التوثيق والتصحيح، فكل ما يوصل إلى هاتين النتيجتين لا ينبغي التتريط فيه. ومما يفيد في التخريج:

المعاجم: العين للخليل، جمهرة اللغة لابن دُرَيْد، ولسان العرب لابن منظور،

$$
\text { وتاج العروس للزَّبِيدي. }
$$

القراء ات: شواذ القراءات لابن خالويه، وشواذ القراءات للكرماني.

معاني القرآن: غريب القرآن لابن قتيبة، والراغب الأصفهاني.

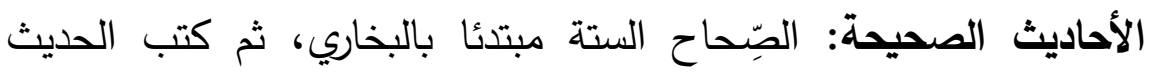

$$
\text { الأخرى عند الحاجة. }
$$

الأحاديث الموضوعة: الموضوعات لابن الجوزي، والأحاديث الموضوعة للثوكاني.

الكلمات المعرَّبة: المعرَّب للجواليقي، وشفاء الغليل للخفاجي. الأماكن والبلدان: معجم ما استعجم للبكري، ومعجم البلدان لياقوت.

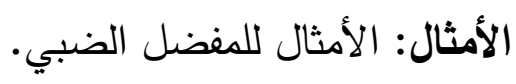

الأعلام: كتب الطبقات والكتب المتخصصة فئل الطئب أعلام كل فن. • إضافة علامات الترقيم حسب ما يقتضيه المعنى.

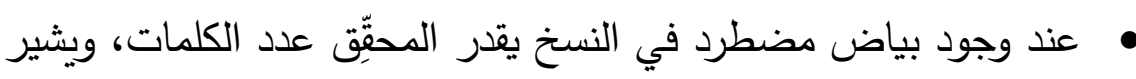
لكل كلمة بثلاث نقط ... ، مع الإثارة إلى ذلك في الحاثية.

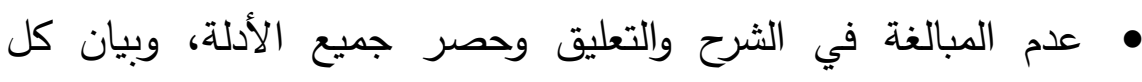
الدذاهب وأوجه الاختلاف حتى لا تثقل الحاشية؛ فتبعث الملل في نفس المتلقي.

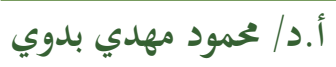
(مدخل إلى تحقيق النصوص التراثية) 
التنبه لأخطاء النساخ: - (التخ

يقع كثير من النساخ - وبخاصة المتأخرين- غير الملمين بقواعد اللغة في أخطاء نحوية، من أثهرها عدم حذف حرف العلة من المضارع عند جزمه،

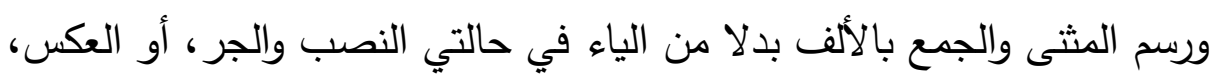
ومطابقة العدد للمعدود في موطن المخالفة والعكس، وتغيير حروف المضارعة، وغير ذلك مما يكتثفه المحقق، وهنا يجب أن يكون المحقق ملمًا بقواعد اللغة، وعليه إصلاح الأخطاء مع الإشارة إلى ما يشيع منها في الدراسة، وذلك بعد

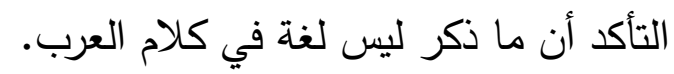

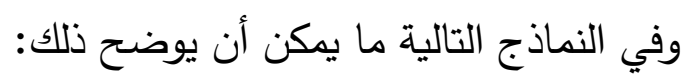

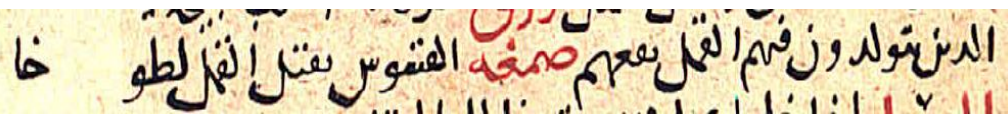
(الذين يتولدون فيهم القعل) القياس يتولد فيهم القمل

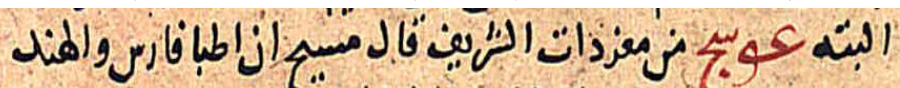

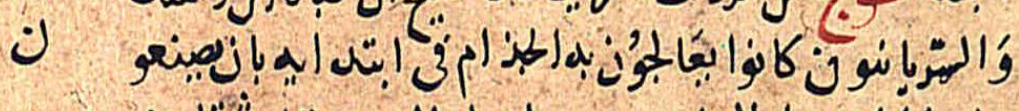

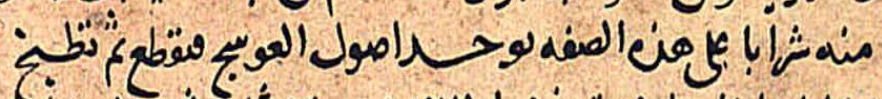

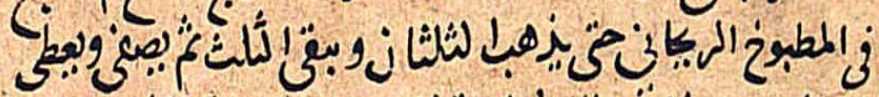

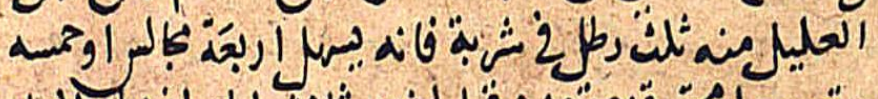

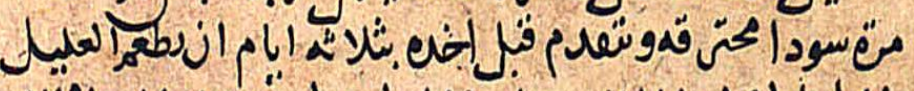

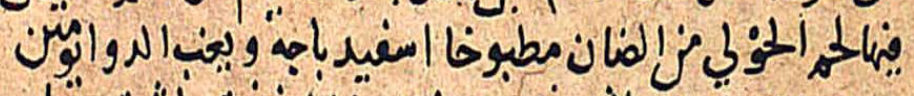

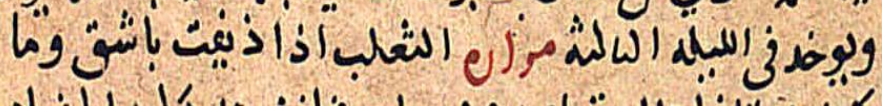
"السريانيون" حقه النصب النصب عطفا على اسم إن، أو الجر عطفا على

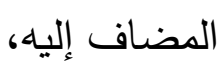


ثبوت النون في المضارع المنصوب ( بأن يصنعون )، والصواب " بأن يصنعوا

الكلمة السادسة بالسطر الثالث جاءت مسقّلة مهملة، فيمكن قراءتها بأكثر

من وجه منها (يوجد، يوحد، يؤخذ )، وهنا على المحقق اختيار الرسم الصحيح الموافق للمعنى ( تؤخذ ).

تسهيل الهمزتين المتوسطة والمتطرفة (ابتدايه، الدوا، سودا، الضان، ويوخذ)، وهو من الأمور الثائعة، وترسم (ابتدائه، الدواء، سوداء، الضأن ويؤخذ).

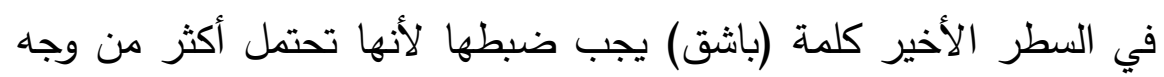

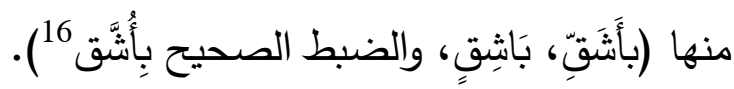

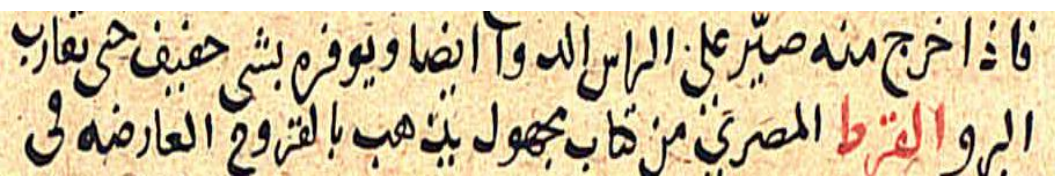
(شي، الراس، الدوا، البرو = شيء، الرأس، الدواء، البرء) إهمال المعجم: حفيف = خفيف، حلى = حتى، القرط = القرظ . رسم التاء المربوطة هاء (العارضه = العارضة) يحذف الناسخ طرف الكاف في كلمة (كتاب) •

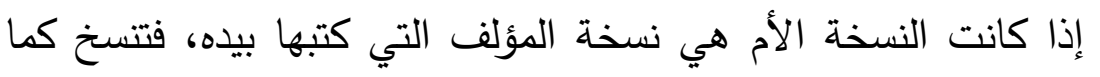
هي بتصحيفها وتحريفها مع الإثارة إلى ذلك في الحاشية، إلا إذا كان الخطأ

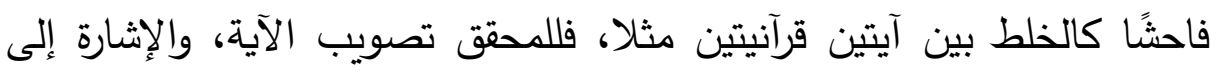

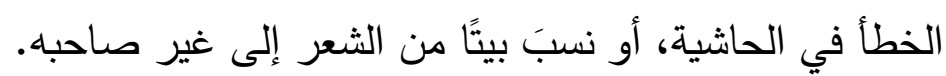


الانتباه لما قد يقع من الناسخ من تبديل لبعض الكلمات، أو حذف أو إضافة أو إقحام الحاشية في المتن أو تبديل لبعض الحروف ـ وأداة المحقق في ضبط ذلك الإمامُ بأسلوب المؤلف، والمقابلة بين النُّنخ، والرجوع لمصادر التأليف، والكتب المؤلفة في الموضوع ذاته.

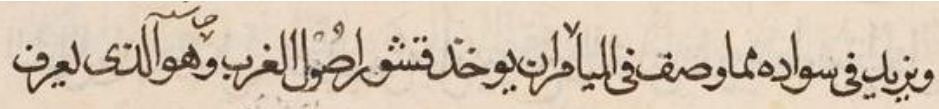

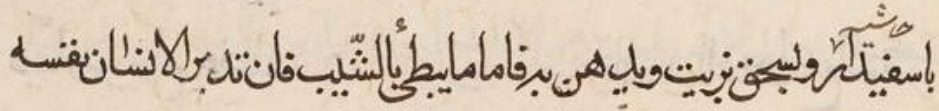
ناسخْ أمين أقحم الحاشية في النص، فحصر المقحَم بكلمتي حاشية.

ثَامنًا: مكمّلات التحقيق:

$$
1 \text { - المكمِّلات القبلية (الدراسة): }
$$

لا يُعنَى كثير من المحققين بمكمِّلات التحقيق القبلية ( الدراسة ) والبعدية (آلـية ) الكثافات )، وهو ما يعدُّ سببًا مرجّحًا لتحقيقٍ آخر يُصدَّر النص ويختم بهذه المكمِّلات، فالدراسة مرآة تعكس ثقافة المحقق ووعيه بالنص وطريقة تعامله معه كي يخرج في صورة أقرب ما تكون إلى ما تركه المؤلف. وإذا كان المؤلف مشهورًا فيُعرَّف به تعريفًا موجزًا مع ذكر مصادر ترجمته لمن يريد الاستزادة، أما إذا كان المؤلف مغمورًا، أو لم يترجم له من قبل فيستحب أن تكون ترجمته وافية. 
عناصر الاراسة الوافية:

أ- عصر المؤلف: يرى كثير من العلماء إمكانية الاستغناء عن هذا

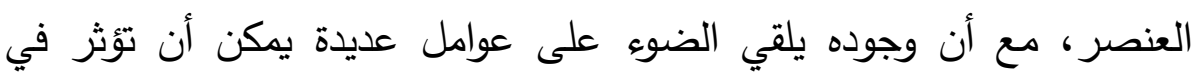
المؤلف والكتاب إيجابًا أو سلبًا؛ لذا فيمكن الاكتفاء بما يحقق الغرض دون إعاء

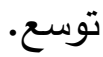

ب- المؤلف وحياته: وفيه يُنكر اسُُ المؤلف، وكنيتُه ونسيُه، ولادته ونشأته، أسرته، طلبه للعلم ورحلاته، شيوخه، مكانته العلمية ووظائفه، تلاميذه، وأقوال

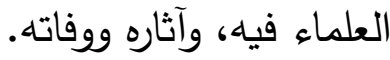
ت- دراسة الكتاب: وتتضمن تحقيق العنوان، واسم المؤلف، ونسبة الكتاب للمؤلف، وسبب التأليف، ومكانة الكتاب بين السابقين واللاحقين، موضوعاته، مصادر تأليفه، منهج المؤلف وأسلوبه، الصصطلحات والرموز • منهج التحقيق، الرموز المعتمدة في التحقيق، وصف النسخ وصفًا دقيقًا ويشمل صفحة العنوان وما عليها من تملكات أو سماعات أو وقف أو قراءات، وكذا صفحة الخاتمة وما تتضمن، ثم بقية عناصر المخطوط المادية، كعدد الأوراق، وعدد السطور في كل صفحة، ونوع الخط ودرجته من حيث معايير الجودة والوضوح، وما في المخطوط من تصحيفات وتحريفات أو سقط، وما على حواشيه من شروح أو وني تعليقات، ونظام ترقيمه...الخ، إدراج نماذج من المخطوطات وبخاصة صفحة العنوان والصفحات الأولى والأخيرة ونهايات الأجزاء وباياتها والصفحات التي منهات بها سمات خاصة كالاضطراب وما شابه. 


\section{تحقيق العنوان:}

لم يعرف المؤلفون قديمًا كتابة العنوان على صفحة الغلاف، لكنه كانوا يصرحون باسم الكتاب في مقدمة الكتاب أو في خاتمته، وهنا يجب على المحقق أن يثبت العنوان الذي صرح به المؤلف، لا الثائع في الكتب أو بين الناس، أو لواء

المثبت على صفحات الغلاف، ويفيد المحقق في ذلك بالطرق التالية: ا-إذا نَصَّ المؤلف على العنوان في خطبة المخطوط، كأن يقول: "وسميته...." كما في النموذجين التاليين:
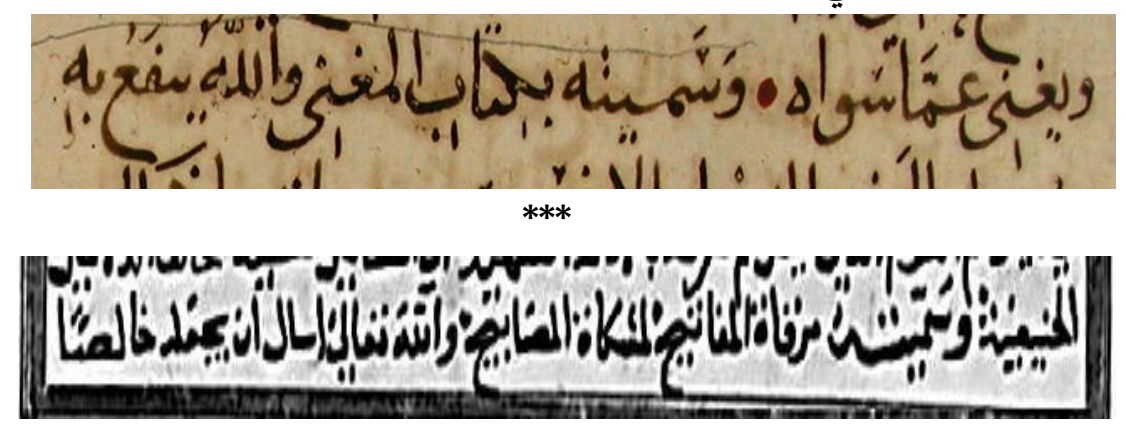

ب-إذا ذكر العنوان في نهاية المخطوط.

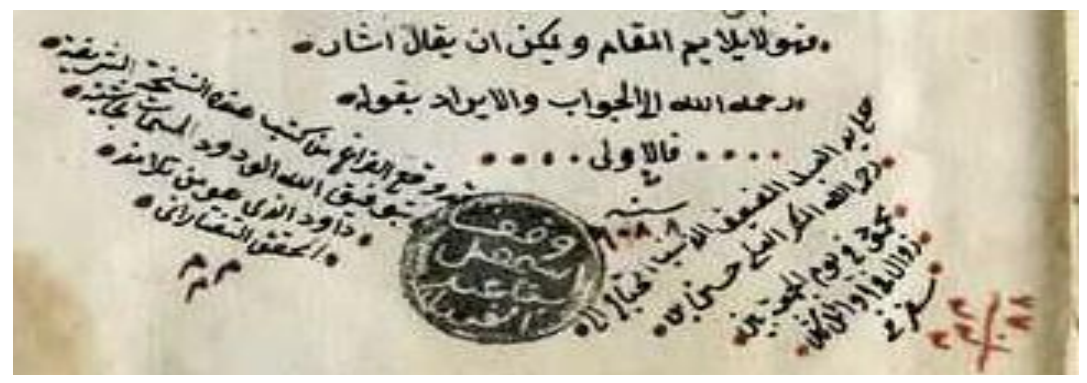

( قد وقع الفراغ من كتب هذه النسخة الشريفة بتوفيق الله الودود المسماة ب"حاشية داود " الذي هو من تلامذة المحقق التقتازاني.

ج-إذا ذكر العنوان على صفحة العنوان وأيدته كتب الطبقات والتراجم. 


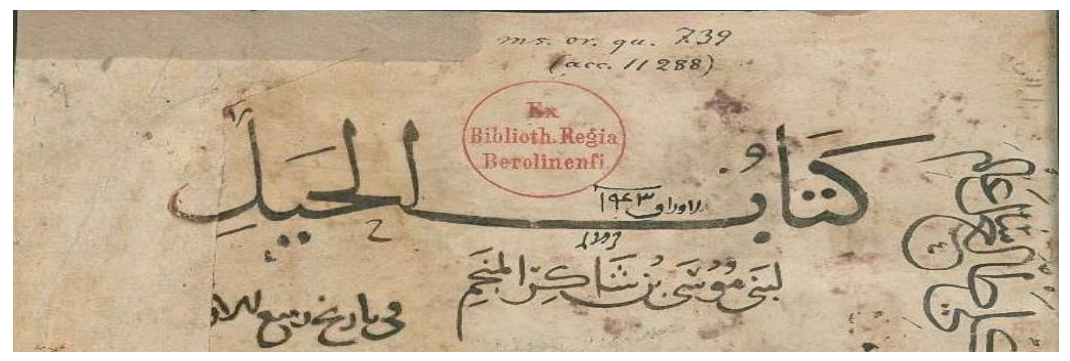

$$
\text { د- تطابق العنوان مع مادة الكتاب. }
$$

هـ - ما يرد بالكتاب من إثارات تاريخية تساعد في معرفة المؤلف وعنوان

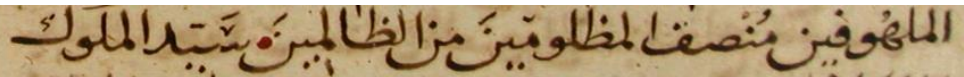

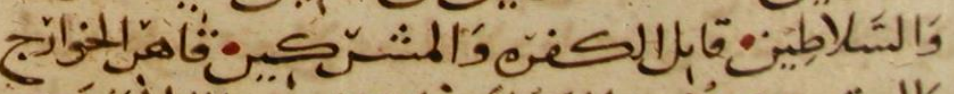

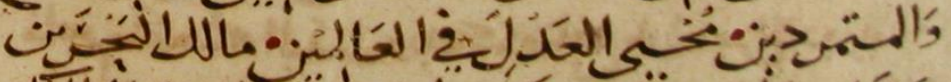

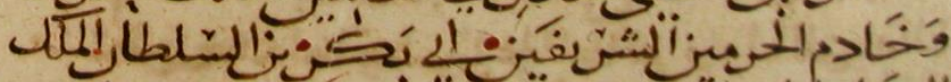

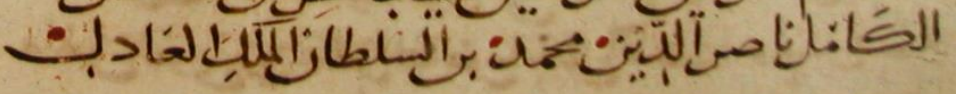

ذِكر المُهََى إليه يفيد في تحديد العصر ويساهم في التعرف على المؤلف تحقيق نسبة الكتاب للمؤلف: ا- إذا ذكر اسم المؤلف في خطبة الكتاب:

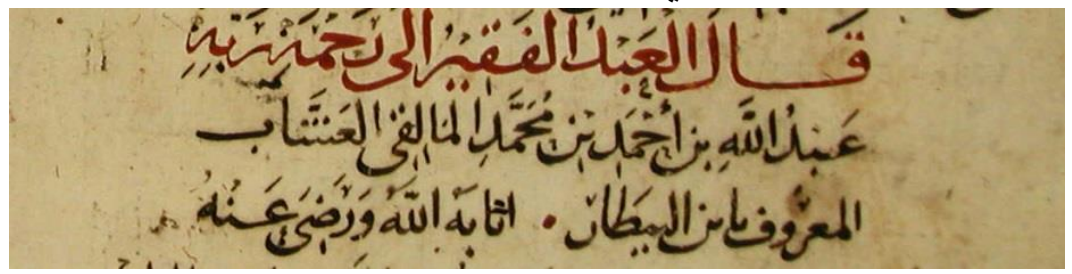

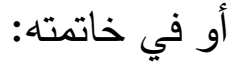




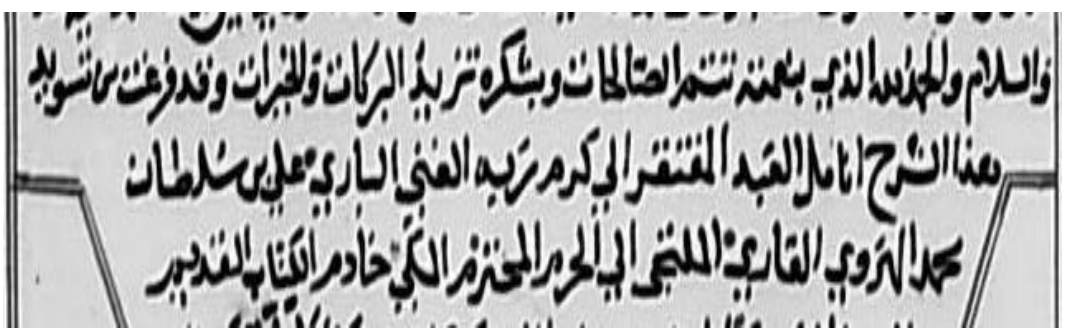

$$
\text { ب-إذا ذكر في صفحة العنوان، وتحتاج هذه المرحلة لمؤكِدات. }
$$

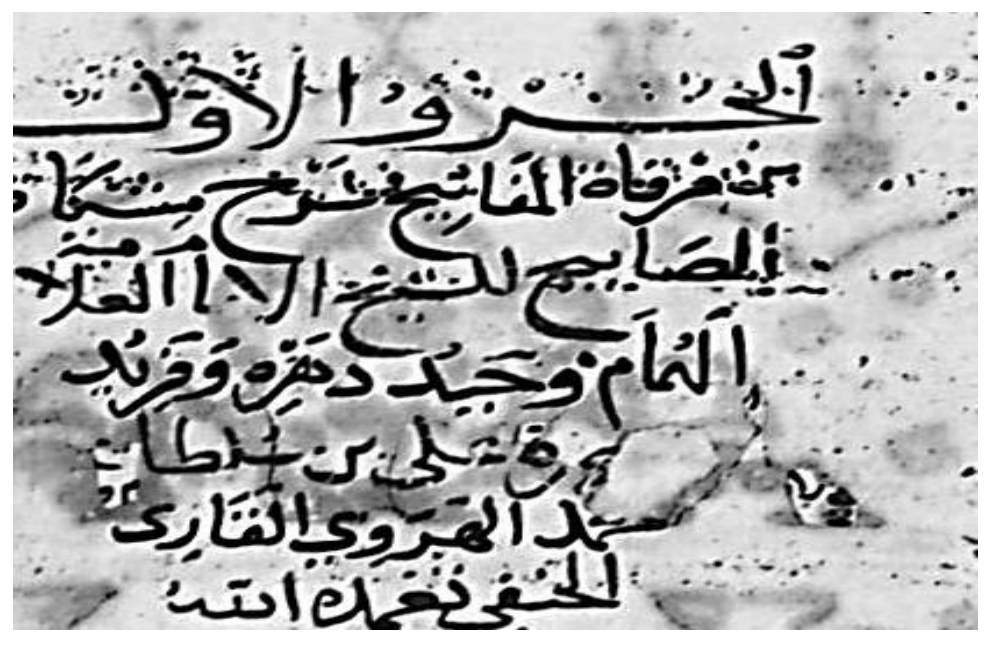

ج - أن يذكر المؤلف أحد شيوخه أو عالمًا معاصرًا معه في الكتاب . 


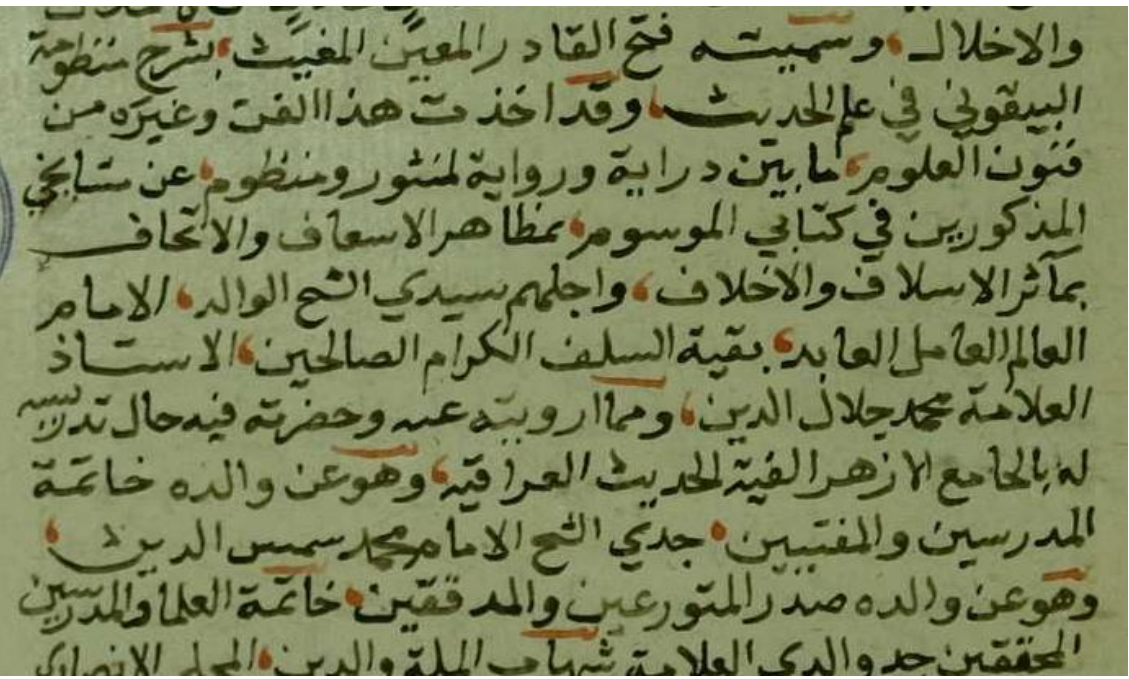

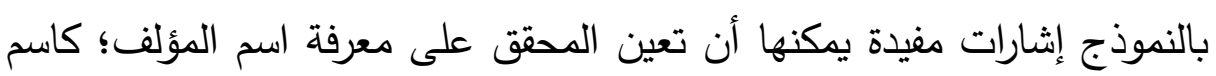

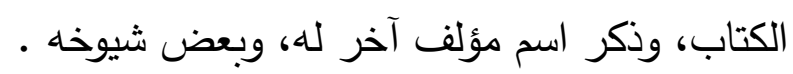
د - الإهداءات: إهداء المؤلف كتابه لسلطان أو أمير أو وزير من الأمور التئي

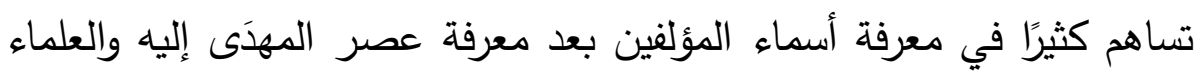
الذي عاصروه وألفوا في موضوع الكتاب.

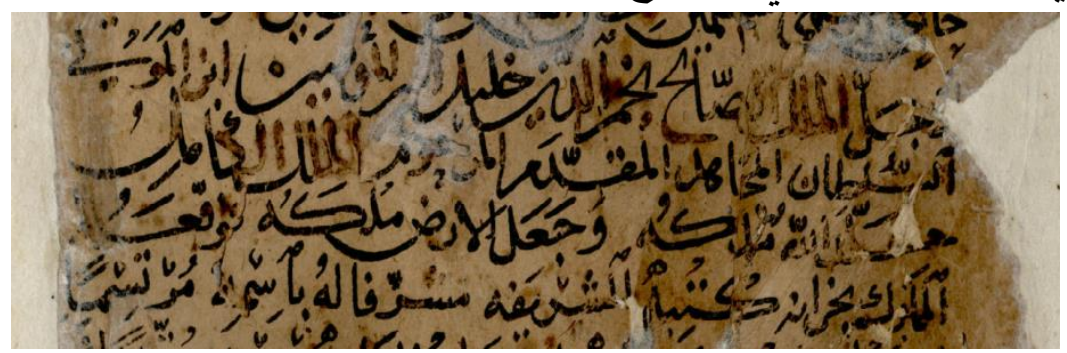

هـ- أن يحيل المؤلف إلى كتاب آخر قام بتأليفه، كما فعل ابن البيطار في

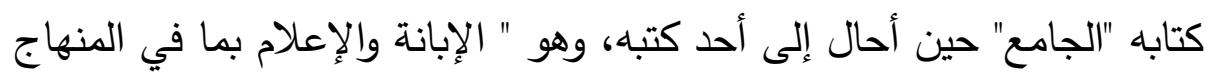
من الخلل والأوهام ". 
ومن ذلك ما ذكره البركوي في خاتمة إحدى مخطوطات كتابه الطريقة المحمدية، والتي جاءت بلا عنوان في المقدمة أو على الغلاف، لكنه أشار في نهاية المخطوطة إلى إحدى رسائله، فكانت الخيط الموصل إلى معرفة عنوان الكتاب واسم المؤلف:

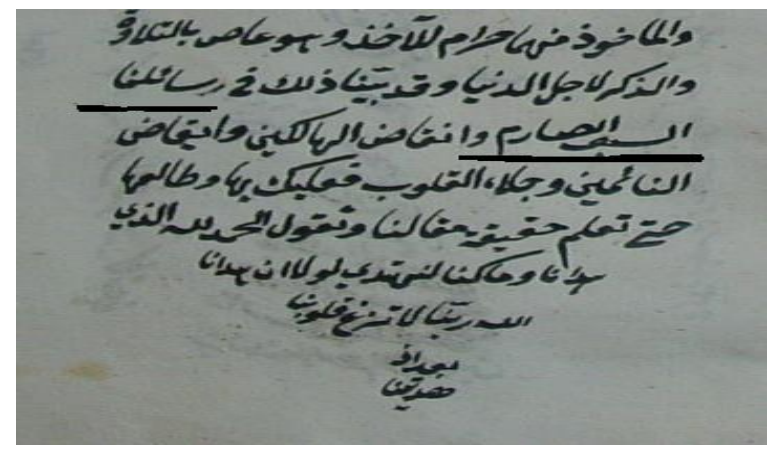

ومن الكتب التي يمكن أن تثيد في هذا العمل كثف الظنون، وهدية

$$
\text { 2- العارفين، وكتب الطبقات والتراجم. }
$$

الكثاف وسيلة توصل المتلقي إلى الوحدات الدقيقة في نص من النصوص،

وتأخذ شكل القوالب أو الأعمدة، وتحتوي على سلسلة من المداخل المقننة المرتبة

ترتيبًا منهجيَّا (هجائيًا في الغالب)، متبوعة بإشارة مكانية (رقم المجلد، الجزء ، الصفحة) لسهولة الوصول إلى المعلومة داخل النص، كما أنها توفر جهد الباحثين والدارسين ووقتهم، وتعينهح على إجراء الإحصاءات والدراسات المقارنة. ويتم تكثيف النص بعد الانتهاء منه تحقيقًا ومراجعة، وبعد أن يأخذ شكله النهائي ترقيمًا، وليس للمحق أن يتعجل في إعداد الكشافات قبل ذلك حتى لا يفسد عمله إن اضطرب الترقيم. 
وهناك مداخل مشتركة يمكن أن نصادفها في أغلب الكتب كالأعلام،

$$
\text { والكتب، والبلدان، والحكم والأمثال }
$$

وهناك مداخل ترتبط بموضوع الكتاب وفنه، فلكتب اللغوية مداخل خاصة بها، ولكتب الفلك، والحديث النبوي، ولكتب التاريخ والسيرة مداخل، ومن المداخل التي يمكن أن يصادفها المحقق في كل ما سبق وغيره: الآيات القرآنية، الأحاديث النبوية، الأعلام، الرواة، رجال السند، البلدان والأماكن، الأمثال، الكتب، الأدوية، الأمراض، الغزوات، البعوث والوفود، المجاعات والنوازل والكوارث، المصطلحات البلاغية والنحوية، اللهجات، الملل والنحل، القبائل، الحيوانات، الباتات، المعادن، الملابس، الأدوات، الأفلاك

$$
\text { والنجوم، الأحجار، الجبال والأنهار والأودية... الخ. }
$$

وهاك نموذجا لكيفية ترتيب المدخل في الكثافات: والكثَّافات عملية شاقة ومرهقة تحتاج من المحقق يقظة وصبرًا، ومما يُكثَّف: 1- الآيات القرآنية: وترتَّب في سورها، ثم ترتب السور حسب ترتيبها في المصحف.

الآية

السورة

182

196

66

48

$$
\text { آل عمران }
$$

آل عمران

يوسف

القلم
الآية

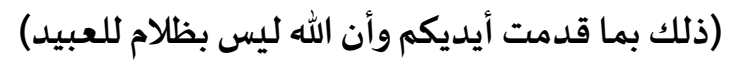

(لا يغرنَّك تقلُّب الذين كفروا في البلاد)

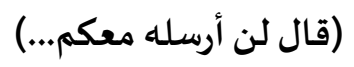

(فاصبر لحكم ربك...) 
ب-الأحاديث النبوية: ترتب بحسب أول حرف من أول كلمة وردت فيها، أو تفهرس على منهج المعجم المفهرس لألفاظ الحديث النبوي. آتي باب الجنة فأخذ بحلقها... ائت الأخنس بن شريك فقل له...

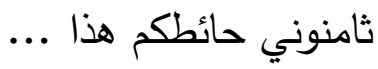
كأن الموت فيها على غيرنا كتب. يأتي آكل الربا يوم القيامة ل...

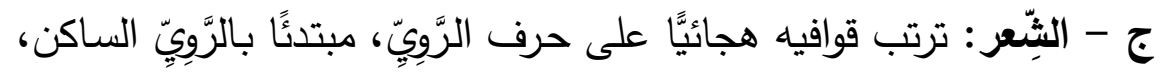
فالمفتوح، فالمضموم، فالمكسور ، ثم يرتب على حسب البحور • ويذكر اسم

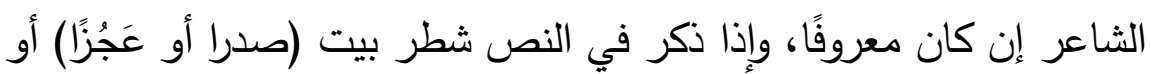
بعض بيت وتمكن المحقق من تكملته، وجب وضـعله في موضسعه من

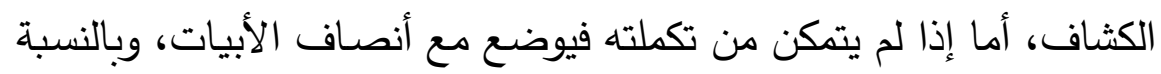
لاسم الثاعر إذا ذكر في النص كتب مجرَّدًا، وإذا كان غير مذكور واهتدى لـان المحقق إليه، ذكره بين قوسين للالالة على أنه كان بلا نسبة في الأصل. ويرى بعض كبار المحقين ضرورة الجمع بين الأبيات وأنصافها في كثاف

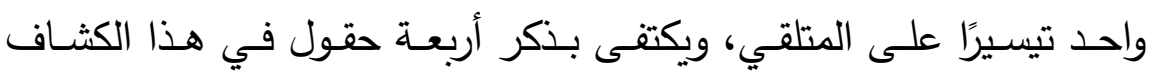

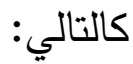




\begin{tabular}{|c|c|c|c|}
\hline الصفحة & الثاعر & البحر & القافية \\
\hline 1 & أحمد شوقي & الكامل & الجوهرا \\
\hline
\end{tabular}

د- الأمثال: ترتب هجائيًا بحسب أولها.

هـ - الأعلام : يستبعد كثير من المحققين " أل " فالحارث مثلا يذكر في حرف الحاء، وبعضهم يستبعد صدور الكنى ( أبو وابن وأم ...) فأبو عمرو مثلا يذكر في حرف العين. ويمكن تكثيف العلم والكنية مـع الإحالة إلى

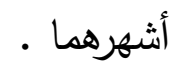
و - ألفاظ اللغة: وترتب حسب الجذر هجائيا. ز - الأماكن والبلدان: ترتب هجائيًا بحسب الحرف الأول. ح - المصطلحات العلمية: وترتب هجائيًا كالأماكن والبلدان. ط - ما يمكن تكشيفه من النص: هناك من يصنع كثافات للموضوعات، وكثافات للألفاظ الغريبة وغير ذلك مما تفرضه طبيعة الكتاب.

تاسعًا: الملاحق:

الملحق: هو ما يُلْحَقُ بالكتاب بعد الفراغ منه، فَتُلْحِقُ بـه ما سقط منـه، أو مـا استدراك عليـه، أو تصـويبات أو تعريفـات أو معلومـات تتعلق بـالنص بعد الانتهاء من تحقيقه وتخريجه وتهيئته للطباعة. 
والبعض يطلق على الملاحق " ذيول "، وهـي جمـع " ذيْلَ"، يقـال: ذَيَّل الثيءً: جعل له ذيلًا.

ويقال: ذَيَّل الصفحة: أي أضاف في هامشها السفليّ سطرًا نصيَّا أو أكثر ،

مُرَكَبًَا من عنصر أو أكثر.

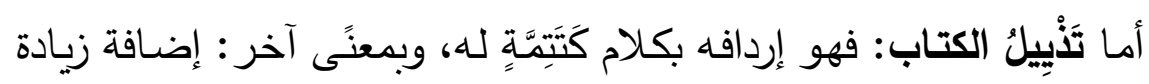
في آخره، وهو مصطلح يستخدمه البعض مرادفا للملاحق. أهمية الملاحق والتذييلات:

1- - تصويب بعض الأخطاء المطبعية.

2- تدارك سطر أو أسطر مما سقط أثناء الطبح.

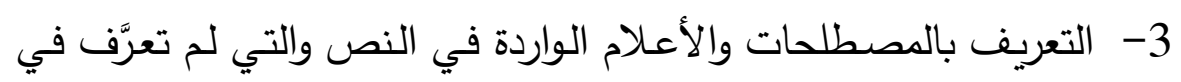

موضعها من صفحات الكتاب.

4- إيضاح وتفسير بعض المفاهيم.

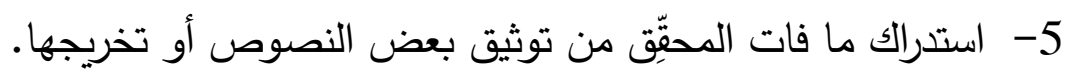

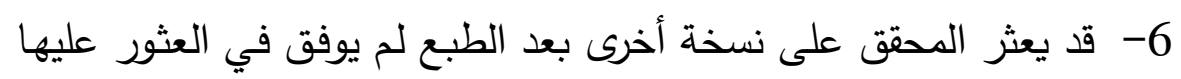
قبل التحقيق أو أثناءه فيلحق بالنص ما فيها من فروق.

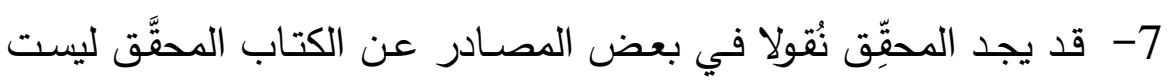
بموجودة فيما تحت يده من نسخ فيعدد لإثباتها في ملحق. 8- قد تضيق هوامش الكتاب عن خدمة النص بما يوضحه للقارئ شرحًا فتكون الملاحق حلا. 
9- إضافة فوائد أخرى ترتبط بموضوع الكتاب يراها المحقق جديرة بالإثبات

كبيان طرق حديثة في حل بعض المسـائل، أو بيـان الأسماء العلميـة لبعض المفردات النباتية، أو إعداد معجم بأسماء المفردات والعناصر والمركبات الواردة في النص بلغات أجنبية حديثة، أو مكتوبة بحروف لغتها الأصلية. وختاما فلابد وأن يعلم المقبل على تحقيق نص تراثي أن هذه العجالة لن تثبع نهما ولن تروي ظمـأ، ولكنها كبل الصدى، فوراء هـا تفصيلات وتفريعات غايـة في الأهمية يجب أن يقف عليها ليصل بعمله إلى غايته المثلى. 


\section{الحواشي:}

1- السقط: ما ينقص من النسخة سواء كان كلمة، أو جملة، أو سطرا، أو

$$
\text { 2- الزيادة: إضافة في الخط(الحروف والكلمات). }
$$

3- التصـحيف: تغييـر في نقط أو شكل الكلمـة مـع بقـاء صـورة الخطـ. والتحريف: هو العدول بالثيء عن جهته التي قد تكون بالزيادة في الكلام، أو النقص منه ،وقد تكون بتبديل بعض كلماته، وقد تكون بحملة على غير المراد منـه. " وللعلماء تفصيلات وآراء في تعريفهما انظرها في "تصحيح

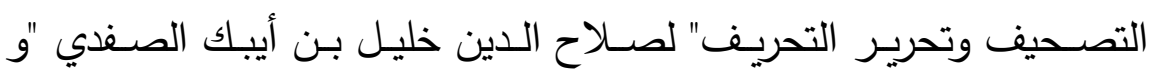
"التبيـه على حدوث التصحيف" لأبي عبد الله حمزة الأصبهاني، و " فتح

$$
\text { المغيث للسخاوي"، وغيرها. }
$$

4- النسـخة الأم أو الأصـل: هـي النسـخة القديمـة التي على رأس الثـجرة النسبية للمخطوطات باستيفائها لمعايير نقد النصوص.

5- قيد الفراغ: ما يسجل في آخر الكتاب لحظة الانتهاء من كتابة النسخة مـن تـاريخ الفـراغ مـن النسـخ، ومكـان النسـخ ووقته، وأحيانـا تـاريخ النسـخة المنقول منها.

6- هو ما يختم به الناسخ الكتاب من معلومات تتعلق بالساخة وبياناتها. 7- المبيضـة: هي نسخة المؤلف التي صـحها ونقحها وارتضـاها وأذاعها في الناس. 8- المسودة: هي الثكل الأوَّلي للكتاب المليء بالمحو والشطب والإضـافة والحذف، وما إلى ذلك. 9- التبيضيض: إخراج الكتاب من المسوَّدة إلى الصورة الأصل. 
10- - يشير البعض إلى وجـه الورقة بحرف (و) وظهرها بحرف (ظ)، ويرقم البعض الوجه بحرف (ا)، والظهر بحرف (ب)، وفي الحالتين يسبق الحرف برقم الورقة هكذا [30/و، - [60/ظ ]، [ 1/30 ]- [66/ب] ، ويضـع البعض الترقيم في أول السطر الذي تبدأ في الصفحة محددا بدايتها بشرطة مائلة / لبنا ، والبعض يضع الترقيم عند بداية الصفحة في وسط الكلام. 11 - 11 الأشق : مفردة دوائية.

$$
\text { المراجع }
$$

1- رسالة حنين بن إسحاق عن ترجمات كتب جالينوس: دراسة وتحليل: ا د كمال عرفات نبهان، جامعة مصر ، ط الأولى: 124. 2- 2 - 2 - السابق:136.

3- أدب المفيد والمستفيد:عبد الباسط بن موسى العلموي، المكتبة العربية،

$$
\text { دمشق:136، 137، } 137 .
$$

4- تحقيق النصـوص ونشـرها: د ـ عبـد السـلام هـارون، مكتبـة الخـانجي، الطبعة السابعة، 1998/1418: 42.

5- الإلماع في ضبط الرواية وتقييد السماع:عياض بن موسى اليحصبي.

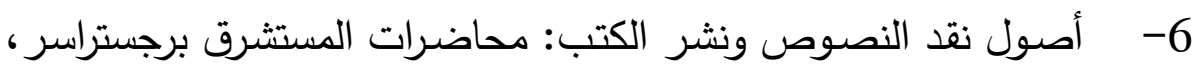
إعداد: د. محمد البكري، دار المريخ، الرياض .

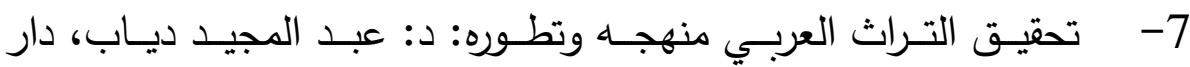
المعارف.

8- قواعد تحقيق المخطوطات: عبد السلام هارون: مكتبة الخانجي، الطبعة السابعة، 1998/1418. 
9- محاضرات في تحقيق النصوص: نـاجي هلال، دار الغرب الإسـلامي،

الطبعة الأولى، 1994.

10- مناهج تحقيق التراث بين القدامى والمحدثين: د. رمضـان عبد التواب، مكتبة الخانجي، الطبعة الأولى، 1985/1406.

11- المنهاج في تأليف البحوث وتحقيق المخطوطات: محمد التونجي، عالم الكتب . 